Atmos. Chem. Phys., 13, 1853-1877, 2013

www.atmos-chem-phys.net/13/1853/2013/

doi:10.5194/acp-13-1853-2013

(C) Author(s) 2013. CC Attribution 3.0 License.

\title{
Radiative forcing of the direct aerosol effect from AeroCom Phase II simulations
}

G. Myhre ${ }^{1}$, B. H. Samset ${ }^{1}$, M. Schulz ${ }^{2}$, Y. Balkanski ${ }^{3}$, S. Bauer ${ }^{4}$, T. K. Berntsen ${ }^{1}$, H. Bian ${ }^{5}$, N. Bellouin ${ }^{6,}$, M. Chin ${ }^{7}$, T. Diehl ${ }^{7,8}$, R. C. Easter $^{9}$, J. Feichter ${ }^{10}$, S. J. Ghan ${ }^{9}$, D. Hauglustaine ${ }^{3}$, T. Iversen ${ }^{2,11}$, S. Kinne ${ }^{10}$, A. Kirkevåg ${ }^{2}$, J.-F. Lamarque ${ }^{12}$, G. Lin ${ }^{13}$, X. Liu ${ }^{8}$, M. T. Lund ${ }^{1}$, G. Luo ${ }^{14}$, X. Ma ${ }^{14}$, T. van Noije ${ }^{15}$, J. E. Penner ${ }^{13}$, P. J. Rasch ${ }^{9}$, A. Ruiz ${ }^{15,16}$, Ø. Seland ${ }^{2}$, R. B. Skeie ${ }^{1}$, P. Stier ${ }^{17}$, T. Takemura ${ }^{18}$, K. Tsigaridis ${ }^{4}$, P. Wang ${ }^{15}$, Z. Wang ${ }^{19}$, L. Xu ${ }^{13,20}$, H. Yu ${ }^{5}$, F. Yu ${ }^{14}$, J.-H. Yoon ${ }^{9}$, K. Zhang ${ }^{10,9}$, H. Zhang ${ }^{21}$, and C. Zhou ${ }^{13}$

${ }^{1}$ Center for International Climate and Environmental Research - Oslo (CICERO), Oslo, Norway

${ }^{2}$ Norwegian Meteorological Institute, Oslo, Norway

${ }^{3}$ Laboratoire des Sciences du Climat et de l'Environnement, CEA-CNRS-UVSQ, Gif-sur-Yvette, France

${ }^{4}$ NASA Goddard Institute for Space Studies and Columbia Earth Institute, New York, NY, USA

${ }^{5}$ Earth System Science Interdisciplinary Center, University of Maryland, College Park, MD, USA

${ }^{6}$ Met Office Hadley Centre, Exeter, UK

${ }^{7}$ NASA Goddard Space Flight Center, Greenbelt, MD, USA

${ }^{8}$ Universities Space Research Association, Columbia, MD, USA

${ }^{9}$ Pacific Northwest National Laboratory, Richland, WA, USA

${ }^{10}$ Max Planck Institute for Meteorology, Hamburg, Germany

${ }^{11}$ Department of Geosciences, University of Oslo, Oslo, Norway

${ }^{12}$ NCAR Earth System Laboratory, National Center for Atmospheric Research, Boulder, CO, USA

${ }^{13}$ Department of Atmospheric, Oceanic, and Space Sciences, University of Michigan, Ann Arbor, Michigan, USA

${ }^{14}$ Atmospheric Sciences Research Center, State University of New York at Albany, New York, USA

${ }^{15}$ Royal Netherlands Meteorological Institute, De Bilt, The Netherlands

${ }^{16}$ LIFTEC, CSIC-Universidad de Zaragoza, Zaragoza, Spain

${ }^{17}$ Department of Physics, University of Oxford, Oxford, UK

${ }^{18}$ Research Institute for Applied Mechanics, Kyushu University, Fukuoka, Japan

${ }^{19}$ Chinese Academy of Meteorological Sciences, Beijing 100081, China

${ }^{20}$ Scripps Institution of Oceanography, University of California, San Diego, La Jolla, California, USA

${ }^{21}$ Laboratory for Climate Studies, National Climate Center, China Meteorological Administration, Beijing 100081, China

*now at: Department of Meteorology, University of Reading, Reading, UK

Correspondence to: G. Myhre (gunnar.myhre@ cicero.uio.no)

Received: 31 July 2012 - Published in Atmos. Chem. Phys. Discuss.: 30 August 2012

Revised: 9 January 2013 - Accepted: 1 February 2013 - Published: 19 February 2013

Abstract. We report on the AeroCom Phase II direct aerosol effect (DAE) experiment where 16 detailed global aerosol models have been used to simulate the changes in the aerosol distribution over the industrial era. All 16 models have estimated the radiative forcing (RF) of the anthropogenic DAE, and have taken into account anthropogenic sulphate, black carbon (BC) and organic aerosols (OA) from fossil fuel, biofuel, and biomass burning emissions. In addition several models have simulated the DAE of anthropogenic nitrate and anthropogenic influenced secondary organic aerosols (SOA). The model simulated all-sky RF of the DAE from total anthropogenic aerosols has a range from -0.58 to $-0.02 \mathrm{Wm}^{-2}$, with a mean of $-0.27 \mathrm{Wm}^{-2}$ for the 16 models. Several models did not include nitrate or SOA and modifying the estimate by accounting for this with information from the other AeroCom models reduces the range and 
slightly strengthens the mean. Modifying the model estimates for missing aerosol components and for the time period 1750 to 2010 results in a mean RF for the DAE of $-0.35 \mathrm{Wm}^{-2}$. Compared to AeroCom Phase I (Schulz et al., 2006) we find very similar spreads in both total DAE and aerosol component RF. However, the RF of the total DAE is stronger negative and RF from $\mathrm{BC}$ from fossil fuel and biofuel emissions are stronger positive in the present study than in the previous AeroCom study. We find a tendency for models having a strong (positive) BC RF to also have strong (negative) sulphate or OA RF. This relationship leads to smaller uncertainty in the total RF of the DAE compared to the RF of the sum of the individual aerosol components. The spread in results for the individual aerosol components is substantial, and can be divided into diversities in burden, mass extinction coefficient (MEC), and normalized RF with respect to AOD. We find that these three factors give similar contributions to the spread in results.

\section{Introduction}

Global estimates of the direct aerosol effect (DAE) have improved tremendously over the last two decades, due to improvements in processes taken into account and handling of complexities in the aerosol schemes (Bauer et al., 2010; Chin et al., 2009; Seland et al., 2008; Stier et al., 2005; Takemura et al., 2002). The first study of radiative forcing (RF) of the DAE with a global aerosol model included only sulphate aerosols (Charlson et al., 1991). Now multi-model studies with multi aerosol components and including some complex aerosol microphysical schemes have been performed (Schulz et al., 2006).

In the estimate of the RF from the direct aerosol effect from AeroCom Phase I models (Schulz et al., 2006) anthropogenic sulphate, black carbon and organic carbon were considered. In the interim increased attention has been given to the direct aerosol effect of anthropogenic nitrate and secondary organic aerosols (SOA). The formation of ammonium nitrate is complex and is dependent on sufficient ammonia and thus competition with sulphate is important (Adams et al., 2001; Metzger et al., 2002). With the expected reduction in $\mathrm{SO}_{2}$ emission in the future, nitrate may become more important as a climate forcer (Bauer et al., 2007; Bellouin et al., 2011). Over the last few years increasing consideration has also been paid to secondary organic aerosols (SOA), with advanced understanding of their anthropogenic influence (Hoyle et al., 2011; Robinson et al., 2007). Anthropogenic influence on SOA is now included with varying degrees of complexity in some global aerosol models (Hoyle et al., 2009; Liao and Seinfeld, 2005; Spracklen et al., 2011; Tsigaridis et al., 2006).

The mean RF of the total direct aerosol effect in Schulz et al. (2006) from 9 global aerosol models was $-0.22 \mathrm{Wm}^{-2}$.
This is much weaker than several observational based estimates (Bellouin et al., 2005, 2008; Chung et al., 2005; Quaas et al., 2008). Observational based estimates have been made possible through the advancement of remote sensing from ground and space (Holben et al., 1998; Remer et al., 2008). Myhre (2009) showed that estimates of the direct aerosol effect must rely on global aerosol model estimates, but consistency between models and observational based methods could be reached by accounting for anthropogenic changes in the aerosol optical properties in the latter method.

Various factors lie behind the large range in the global estimates of the DAE, which in AeroCom Phase I was from -0.41 to $+0.04 \mathrm{Wm}^{-2}$ (Schulz et al., 2006). Schulz et al. (2006) showed that the variations in RF could be separated into diversities in aerosol residence time, aerosol mass extinction coefficients, and normalized forcing (RF divided by aerosol optical depth). Normalized forcing was found to be the single largest contributor to the variability. Differences in the aerosol vertical profile, known to be significant between the models, is among the factors that contribute to differences in the normalized RF (Heald et al., 2011; Schwarz et al., 2010; Textor et al., 2006; Zarzycki and Bond, 2010).

In this paper RF of the DAE from 16 recent state-of-theart global aerosol models in the AeroCom Phase II are presented. Two of the 16 global aerosol models are from Asia, six from Europe and eight from North America. Additional models compared to Schulz et al. (2006) are included in Phase II, and the models have been further developed over the 7-8 yr since AeroCom Phase I. Results for anthropogenic nitrate and SOA are included in the present study. Evaluation of the global aerosol models is an ongoing activity within AeroCom, with comparisons of various measurements being performed (Huneeus et al., 2011; Koch et al., 2009; Koffi et al., 2012). Activities to understand the model differences are also an important part of AeroCom (Randles et al., 2012; Samset et al., 2012; Stier et al., 2012; Textor et al., 2007).

\section{Methods}

The RF of the total anthropogenic DAE is calculated as the difference between the reflected solar radiation at TOA for simulations with present (2000, or 2006 for a few models) and pre-industrial (1850) emissions of aerosols and their precursors, denoted respectively as CTRL and PRE simulations, but the same cloud and surface conditions. The RF has been simulated by 16 global aerosol models with various complexities with regard to number of aerosol species included, aerosol microphysical treatment and their aerosol optical properties. The host model is also of great importance since aerosol transport and removal is dependent on the transport scheme and distribution of precipitation, respectively. In the radiative transfer calculations cloud distribution and properties and surface albedo, among other factors, are important. 
Table 1. Model description, general information. If meteorology was nudged or driven by reanalysis fields, the year 2006 meteorology was used.

\begin{tabular}{|c|c|c|c|c|c|}
\hline Model & Type & Resolution & Levels & Meteorology & Responsible \\
\hline $\mathrm{BCC}$ & GCM & $2.8^{\circ} \times 2.8^{\circ}$ & 26 & NCEP/NCAR reanalysis & $\begin{array}{l}\text { Hua Zhang } \\
\text { Zhili Wang }\end{array}$ \\
\hline CAM4-Oslo & GCM & $2.5^{\circ} \times 1.8^{\circ}$ & 26 & $\begin{array}{l}\text { Produced by CAM } 4 \text { atmospheric physics with CAM4- } \\
\text { Oslo cloud tuning and boundary data from the data ocean } \\
\text { and sea-ice models of CCSM4. }\end{array}$ & $\begin{array}{l}\text { Alf Kirkevåg } \\
\text { Trond Iversen } \\
\text { Øyvind Seland }\end{array}$ \\
\hline CAM5.1 & GCM & $2.5^{\circ} \times 1.8^{\circ}$ & 30 & CAM5.1 & $\begin{array}{l}\text { X. Liu } \\
\text { R. C. Easter } \\
\text { Steve Ghan } \\
\text { P. J. Rasch } \\
\text { J.-H. Yoon }\end{array}$ \\
\hline GEOS-Chem & CTM & $5.0^{\circ} \times 4.0^{\circ}$ & 47 & GEOS-5, reanalysis, nudged & $\begin{array}{l}\text { Fangqun Yu } \\
\text { Gan Luo } \\
\text { Xiaoyan Ma }\end{array}$ \\
\hline GISS-MATRIX & GCM & $2.5^{\circ} \times 2.0^{\circ}$ & 40 & Nudged to NCEP winds & $\begin{array}{l}\text { Susanne Bauer } \\
\text { Kostas Tsigaridis }\end{array}$ \\
\hline GISS-modelE & GCM & $2.5^{\circ} \times 2.0^{\circ}$ & 40 & Nudged to NCEP winds & $\begin{array}{l}\text { Kostas Tsigaridis } \\
\text { Susanne Bauer }\end{array}$ \\
\hline GMI & CTM & $2.5^{\circ} \times 2.0^{\circ}$ & 72 & GEOS-5 MERRA reanalysis for 2006, nudged & $\begin{array}{l}\text { Huisheng Bian } \\
\text { Hongbin Yu }\end{array}$ \\
\hline GOCART & CTM & $2.5^{\circ} \times 2.0^{\circ}$ & 30 & $\begin{array}{l}\text { GEOS-4 DAS (Goddard Earth Observing System version } \\
4 \text { Data Assimilation System), reanalysis for year } 2006\end{array}$ & $\begin{array}{l}\text { Thomas Diehl } \\
\text { Mian Chin }\end{array}$ \\
\hline IMPACT & CTM & $5.0^{\circ} \times 4.0^{\circ}$ & 46 & DAO assimilation fields for 1997, reanalysis. & $\begin{array}{l}\text { Guangxing Lin } \\
\text { Joyce Penner } \\
\text { Li Xu } \\
\text { Cheng Zhou }\end{array}$ \\
\hline INCA & GCM & $3.8^{\circ} \times 1.9^{\circ}$ & 19 & $\begin{array}{l}\text { ECMWF reanalysis from the Integrated Forecast System } \\
\text { (IFS) model for year } 2006 .\end{array}$ & $\begin{array}{l}\text { Yves Balkanski } \\
\text { Michael Schulz } \\
\text { Didier Hauglus- } \\
\text { taine }\end{array}$ \\
\hline HadGEM2 & GCM & $1.8^{\circ} \times 1.2^{\circ}$ & 38 & ERA Interim data for 2006, nudged & Nicolas Bellouin \\
\hline ECHAM5-HAM & GCM & $1.8^{\circ} \times 1.8^{\circ}$ & 31 & Model nudged with ECMWF analysis for the year 2006 & $\begin{array}{l}\text { Kai Zhang } \\
\text { Philip Stier } \\
\text { Johann Feichter }\end{array}$ \\
\hline NCAR-CAM3.5 & GCM & $2.5^{\circ} \times 1.9^{\circ}$ & 26 & GCM-generated & $\begin{array}{l}\text { Jean-Francois } \\
\text { Lamarque }\end{array}$ \\
\hline OsloCTM2 & CTM & $2.8^{\circ} \times 2.8^{\circ}$ & 60 & $\begin{array}{l}\text { ECMWF reanalysis from the Integrated Forecast System } \\
\text { (IFS) model for year } 2006\end{array}$ & $\begin{array}{l}\text { Gunnar Myhre } \\
\text { Ragnhild B. Skeie } \\
\text { Terje Berntsen }\end{array}$ \\
\hline SPRINTARS & GCM & $1.1^{\circ} \times 1.1^{\circ}$ & 56 & $\begin{array}{l}\text { NCEP/NCAR reanalysis (temperature and horizontal } \\
\text { wind),nudged. }\end{array}$ & $\begin{array}{l}\text { Toshihiko Take- } \\
\text { mura }\end{array}$ \\
\hline TM5 & CTM & $3.0^{\circ} \times 2.0^{\circ}$ & 34 & ECMWF ERA-Interim reanalysis for year 2006 & $\begin{array}{l}\text { Twan van Noije } \\
\text { Ping Wang } \\
\text { Ana Ruiz }\end{array}$ \\
\hline
\end{tabular}

Tables 1 and 2 show a list of the models included in the AeroCom Phase II DAE experiment, together with the resolutions used, aerosols components treated and comments on their microphysics scheme. Meteorological data for year 2006 have been used for all the models, except for IMPACT with meteorological data for 1997 and for CAM4-Oslo, NCAR-CAM3.5, and CAM5.1 where nudging possibilities were not available. A protocol describing the data submitted from the global aerosol models are available from the Ae-
roCom web site (http://aerocom.met.no/aerocomhome.html). Most of the simulations for this DAE experiment are performed with identical cloud cover and cloud optical properties in PRE and CTRL, i.e. no indirect aerosol effects are included, but one (CAM5.1) estimated the DAE from the CTRL-PRE difference $(\Delta)$ in the direct radiative forcing by all aerosols in each simulation (Ghan et al., 2012): $\Delta$ (S$\left.\mathrm{S}_{\text {clean }}\right)$, where $\mathrm{S}$ is the net downward solar at TOA calculated 
Table 2. Model description, aerosol information.

\begin{tabular}{|c|c|c|c|c|c|c|c|c|}
\hline Model & $\mathrm{S}$ & $\mathrm{BC}$ & OC & $\mathrm{BB}$ & SOA & $\mathrm{NO}_{3}$ & Aerosol microphysics & $\begin{array}{l}\text { References for aerosol } \\
\text { module }\end{array}$ \\
\hline $\mathrm{BCC}$ & $\mathrm{Y}$ & $\mathrm{Y}$ & $\mathrm{Y}$ & $\mathrm{Y}$ & - & - & $\begin{array}{l}12 \text { bin sizes for each aerosol with radii be- } \\
\text { tween } 0.005-0.01,0.01-0.02,0.02-0.04 \text {, } \\
0.04-0.08,0.08-0.16,0.16-0.32,0.32- \\
0.64,0.64-1.28,1.28-2.56,2.56-5.12 \text {, } \\
5.12-10.24 \text {, and } 10.24-20.48 \mu \mathrm{m} \text {. }\end{array}$ & Zhang et al. (2012a) \\
\hline CAM4-Oslo & $\mathrm{Y}$ & $\mathrm{Y}$ & $\mathrm{Y}$ & $\mathrm{Y}$ & - & - & $\begin{array}{l}\text { Mass conc. of } \mathrm{SO}_{4}, \mathrm{BC}, \mathrm{OM} \text {, sea-salt and } \\
\text { dust in four size-classes are tagged ac- } \\
\text { cording to production mechanism. Based } \\
\text { on } 44 \text { sectional size bins and lognor- } \\
\text { mal distributions at the point of emission, } \\
\text { look-up tables yield physical properties of } \\
\text { the processed aerosols. }\end{array}$ & Kirkevåg et al. (2012) \\
\hline CAM5.1 & $\mathrm{Y}$ & $\mathrm{Y}$ & $\mathrm{Y}$ & $\mathrm{Y}$ & $\mathrm{Y}$ & - & 3 internally-mixed log-normal modes & Liu et al. (2012) \\
\hline GEOS-Chem & $\mathrm{Y}$ & $\mathrm{Y}$ & $\mathrm{Y}$ & - & $\mathrm{Y}$ & $\mathrm{Y}$ & $\begin{array}{l}40 \text { bins for secondary particles, } 20 \text { bins } \\
\text { for sea salt, } 15 \text { bins for dust, } 4 \text { log-normal } \\
\text { modes for BC and primary OC. Coating } \\
\text { of primary particles by secondary species } \\
\text { tracked. Extended SOA formation consid- } \\
\text { ering oxidation aging. }\end{array}$ & $\begin{array}{l}\text { Yu and Luo (2009); } \\
\text { Yu (2011); Ma et al. (2012) }\end{array}$ \\
\hline GISS-MATRIX & $\mathrm{Y}$ & $\mathrm{Y}$ & $\mathrm{Y}$ & $\mathrm{Y}$ & - & $\mathrm{Y}$ & Aerosol microphysical scheme & Bauer et al. $(2008,2010)$ \\
\hline GISS-modelE & $\mathrm{Y}$ & $\mathrm{Y}$ & Y & $\mathrm{Y}$ & $\mathrm{Y}$ & Y & Aerosol mass based scheme & $\begin{array}{l}\text { Koch et al. (2007, 2006); } \\
\text { Bauer et al. (2007); } \\
\text { Tsigaridis et al. (2013) }\end{array}$ \\
\hline GMI & $\mathrm{Y}$ & $\mathrm{Y}$ & $\mathrm{Y}$ & $\mathrm{Y}$ & - & $\mathrm{Y}$ & $\begin{array}{l}5 \text { bin sizes for dust, } 4 \text { bin sizes for sea- } \\
\text { salt, } 3 \text { bin size for nitrate and sulfate, } \\
\text { all aerosols with log-normal size distribu- } \\
\text { tions. }\end{array}$ & Bian et al. (2009) \\
\hline GOCART & $\mathrm{Y}$ & $\mathrm{Y}$ & $\mathrm{Y}$ & $\mathrm{Y}$ & $\mathrm{Y}$ & - & $\begin{array}{l}\text { Parameterized with prescribed dry parti- } \\
\text { cle sizes: } 8 \text { bins for dust, } 4 \text { bins for sea } \\
\text { salt, } 1 \text { bin for sulfate, BC, and OA, with } \\
\text { log-normal distributions, particle growth } \\
\text { parameterized as a function of RH }\end{array}$ & $\begin{array}{l}\text { Chin et al. (2000, 2002, } \\
\text { 2009); Ginoux et al. (2001) }\end{array}$ \\
\hline IMPACT & $\mathrm{Y}$ & $\mathrm{Y}$ & Y & $\mathrm{Y}$ & $\mathrm{Y}$ & $*$ & $\begin{array}{l}4 \text { bin sizes for sea-salt and mineral dust, } \\
\text { pure sulfate treated using } 2 \text { modes with } \\
\text { predicted size and coagulation and con- } \\
\text { densation of SO4 with other aerosols ex- } \\
\text { plicitly resolved. }\end{array}$ & $\begin{array}{l}\text { Wang and Penner (2009); } \\
\text { Lin et al. (2012); } \\
\text { Xu and Penner (2012) }\end{array}$ \\
\hline INCA & $\mathrm{Y}$ & $\mathrm{Y}$ & $\mathrm{Y}$ & $\mathrm{Y}$ & - & $\mathrm{Y}$ & $\begin{array}{l}\text { Soluble and insoluble aerosol treated } \\
\text { separately, modal assumptions with log- } \\
\text { normal size distributions. We distinguish } \\
\text { between accumulation, coarse and super } \\
\text { coarse modes. }\end{array}$ & $\begin{array}{l}\text { Balkanski et al. (2004); } \\
\text { Schulz (2007); } \\
\text { Balkanski (2011); } \\
\text { Szopa et al. (2012) }\end{array}$ \\
\hline HadGEM2 & $\mathrm{Y}$ & $\mathrm{Y}$ & $\mathrm{Y}$ & $\mathrm{Y}$ & - & $\mathrm{Y}$ & $\begin{array}{l}\text { Component aerosol mass transported in } \\
\text { Aitken, accumulation, coarse, and dis- } \\
\text { solved modes. Size distributions assumed } \\
\text { lognormal for interaction with radiation. }\end{array}$ & Bellouin et al. (2011) \\
\hline ECHAM5-HAM & $\mathrm{Y}$ & $\mathrm{Y}$ & $\mathrm{Y}$ & $\mathrm{Y}$ & $\mathrm{Y}$ & - & $\begin{array}{l}\text { Modal method, log-normal size distribu- } \\
\text { tions, } 7 \text { modes ( } 4 \text { soluble, } 3 \text { insoluble). In- } \\
\text { ternal mixing is assumed for aerosol com- } \\
\text { positions considered in each mode, while } \\
\text { external mixing is assumed among differ- } \\
\text { ent aerosol modes. }\end{array}$ & $\begin{array}{l}\text { Vignati et al. (2004); } \\
\text { Stier et al. (2005); } \\
\text { Zhang et al. (2012b) }\end{array}$ \\
\hline
\end{tabular}


Table 2. Continued.

\begin{tabular}{|c|c|c|c|c|c|c|c|c|}
\hline Model & $\mathrm{S}$ & $\mathrm{BC}$ & OC & $\mathrm{BB}$ & SOA & $\mathrm{NO}_{3}$ & Aerosol microphysics & $\begin{array}{l}\text { References for aerosol } \\
\text { module }\end{array}$ \\
\hline NCAR-CAM3.5 & $\mathrm{Y}$ & $\mathrm{Y}$ & $\mathrm{Y}$ & $\mathrm{Y}$ & - & $\mathrm{Y}$ & $\begin{array}{l}\text { Bulk-aerosol model, except 4-bins for } \\
\text { sea-salt and mineral dust }\end{array}$ & Lamarque et al. (2012) \\
\hline OsloCTM2 & $\mathrm{Y}$ & $\mathrm{Y}$ & $\mathrm{Y}$ & $\mathrm{Y}$ & $\mathrm{Y}$ & $\mathrm{Y}$ & $\begin{array}{l}8 \text { bin sizes for sea-salt and mineral dust, } \\
\text { aerosol mass scheme for other aerosols } \\
\text { with log-normal size distributions in cal- } \\
\text { culations of optical properties }\end{array}$ & $\begin{array}{l}\text { Myhre et al. (2007, 2009); } \\
\text { Skeie et al. (2011) }\end{array}$ \\
\hline SPRINTARS & $\mathrm{Y}$ & $\mathrm{Y}$ & $\mathrm{Y}$ & $\mathrm{Y}$ & - & - & $\begin{array}{l}6 \text { bins for dust, } 4 \text { bins for sea salt, } 1 \text { bin } \\
\text { for sulfate, BC, and OA, with log-normal } \\
\text { size distributions and particle growth as a } \\
\text { function of relative humidity }\end{array}$ & $\begin{array}{l}\text { Takemura et al. } \\
(2005,2009)\end{array}$ \\
\hline TM5 & $\mathrm{Y}$ & $\mathrm{Y}$ & $\mathrm{Y}$ & Y & Y & $\mathrm{Y}$ & $\begin{array}{l}\text { Modal method, log-normal size distribu- } \\
\text { tions, } 7 \text { modes ( } 4 \text { soluble, } 3 \text { insoluble). In- } \\
\text { ternal mixing is assumed for aerosol com- } \\
\text { positions considered in each mode, while } \\
\text { external mixing is assumed among differ- } \\
\text { ent aerosol modes. }\end{array}$ & $\begin{array}{l}\text { Vignati et al. (2004); } \\
\text { Aan de Brugh et al. (2011) }\end{array}$ \\
\hline
\end{tabular}

Note: GOCART only includes SOA from biogenic sources (terpene oxidation)

* The $\mathrm{NO}_{3}$ values for forcing from this model were simulated using the same model as the IMPACT model described here, but did not include the chemistry of formation of $\mathrm{SOA}$ and used the simplified $\mathrm{NO}_{\mathrm{X}}$ chemistry described in Feng and Penner (2007). The resolution was $2.5 \times 2.0$.

with all aerosols present, and $S_{\text {clean }}$ is the solar calculated neglecting scattering and absorption by all aerosols.

Aerosol optical properties are treated differently in the global aerosol models but in all models the optical properties are derived using Mie theory; see further description in model references. All models include treatment of sulphate, black carbon, primary organic carbon, sea salt, and mineral dust. Internal mixing between $\mathrm{BC}$ and scattering aerosols enhances the absorption from BC (Fuller et al., 1999; Haywood and Shine, 1995), and half of the 16 models include some degree of internal mixture for BC. Most of the models have used emissions of aerosols and their precursors from Lamarque et al. (2010). CAM4-Oslo and SPRINTARS have used these IPCC AR5 emissions for PRE (year 1850), but for the CTRL simulations emissions for year 2006 from the AeroCom Phase II dataset has been used (HCA0 v1 or v2 by T. Diehl, see http://aerocom.met.no/emissions.html). This dataset also includes emissions estimates of $\mathrm{BC}, \mathrm{SO}_{2}$ and POM from aviation. BCC used year 2000 emissions, but preindustrial emissions for 1750. GEOS-Chem uses emissions for 2006 which is close to AeroCom emission for 2000 and employs pre-industry emission corresponding to 1750 (Dentener et al., 2006). TM5 used 1850 emissions from Lamarque et al. (2010) and for 2006 a linear interpolation between 2005 and 2010 for the representative concentration pathway RCP4.5 (Thomson et al., 2011).

If the diagnostics for the different components were difficult to establish, separate model simulations were performed to allow for an attribution to eg biomass burning (BB) or fossil fuel (FF) and bio fuel (BF) sources. For some of the models with internally-mixed aerosols the separation of AOD and RF by aerosol component is challenging. Several groups have solved this by additional radiation calls. Even with this method a few models have been unable to properly extract the component AOD. Where relevant, these results have been removed from the analysis. All simulations were performed such that the cloud fields were identical, e.g. by neglecting the influence of aerosols on clouds or keeping the influence constant.

Only anthropogenic aerosol effects will be treated in the present study, and reference to the DAE apply to the anthropogenic change in the aerosol distribution and its influence on the scattering and absorption of solar radiation. Results will be presented for sulphate, nitrate, $\mathrm{BC}$ from fossil fuel and biofuel, OA from fossil fuel and biofuel, BC and OA combined from biomass burning, and SOA.

\section{Results}

All results are for anthropogenic aerosols only, unless otherwise stated. Anthropogenic aerosols are defined as the difference between the CTRL and PRE simulations described above.

\subsection{Total direct aerosol effect}

The underlying albedo is crucial for RF of the direct aerosol effect (Haywood and Shine, 1995). Scattering aerosols are efficient at producing a RF over dark surfaces and absorbing aerosols are efficient over bright surfaces. Figure 1a shows the latitudinal variation of the top of the atmosphere (TOA) albedo of the 16 models and the satellite retrieval from 


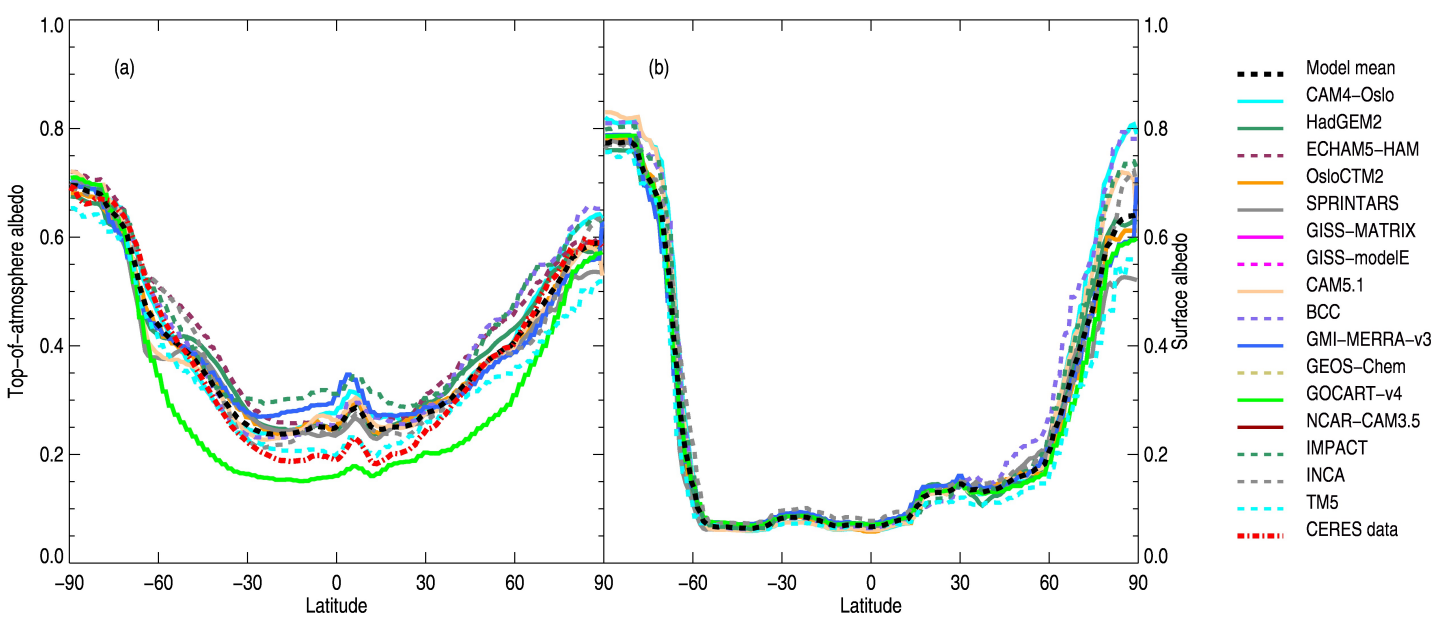

Fig. 1. Zonal mean top of the atmosphere short wave (TOA) albedo (a) and effective broadband surface albedo (b) shown for all the models. CERES TOA albedo data is shown together with the models.
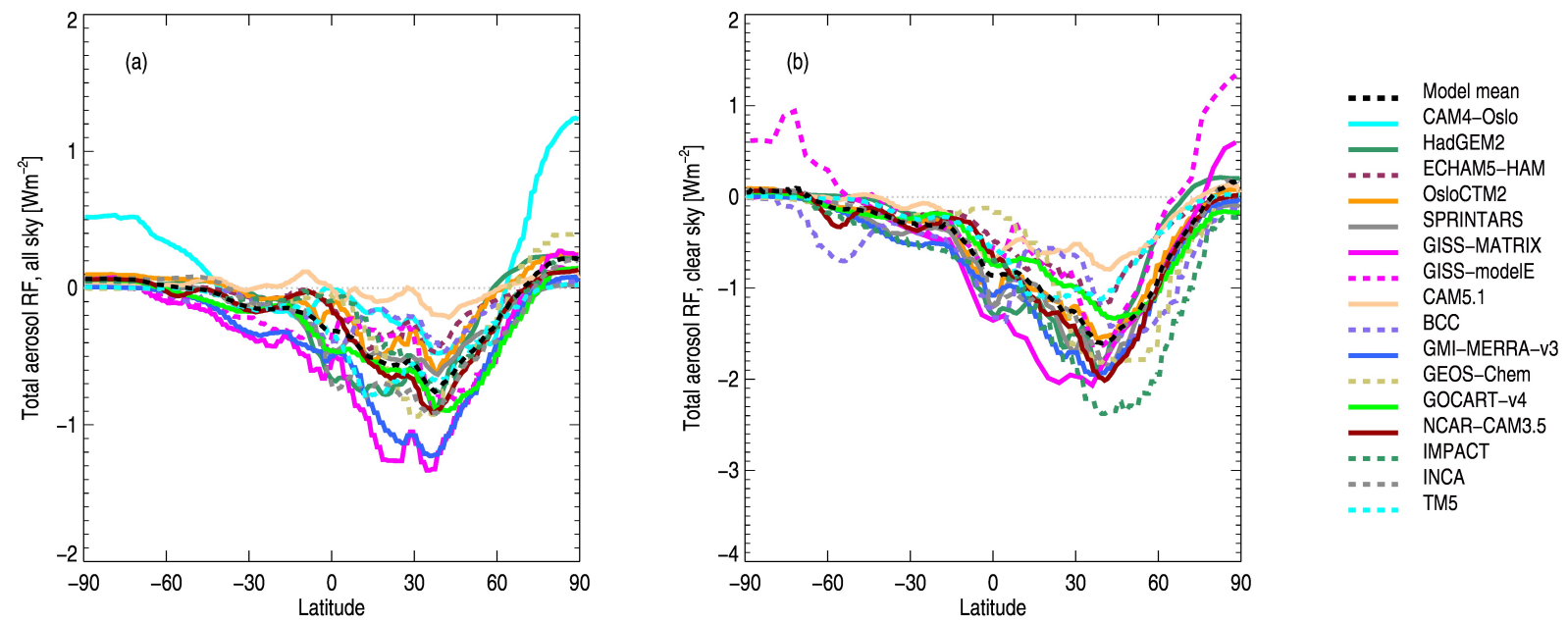

Fig. 2. Zonal mean DAE RF for all-sky (a) and RF for clear sky (b).

CERES (Smith et al., 2011; Wielicki et al., 1996). Note that the albedo at the TOA consists of reflection at the surface and scattering in the atmosphere from clouds, aerosols, and Rayleigh scattering, and thus the scattering may occur above the anthropogenic aerosols. The higher albedo at high latitudes is mainly due to high surface albedo from snow and ice, but larger cloud fraction also contributes. For most of the models the albedo compares well to the CERES data, except between $30^{\circ} \mathrm{N}$ and $30^{\circ} \mathrm{S}$ where almost all overestimate the albedo. By inspection of the geographical distribution (not shown) of the albedo the overestimation is largest in regions with low cloud fraction, indicating problems with too large cloud fractions in these regions for the models. The GOCART model has a very low albedo compared to the rest of the models and the CERES data, which is identified to be caused by the meteorological data. The agreement between the simulated latitudinal variation in effective broad- band surface albedo (computed from surface level down and up welling short wave radiation fluxes as diagnosed in the models) is in general excellent (see Fig. 1b), except at high latitudes due to differences in snow cover or albedo for snow and for the Northern Hemisphere sea ice coverage and albedo for sea ice.

Figure 2 shows the latitudinal variation in the RF of the total DAE for all sky (Fig. 2a) and clear sky (Fig. 2b) conditions. The negative RF is at maximum around $30^{\circ} \mathrm{N}$ for most of the models, since the anthropogenic change in aerosol burden (see Fig. 3) has its maximum in this region combined with a relatively high solar radiation flux. GISS-Matrix and GMI have the strongest all-sky RF in the Northern Hemisphere, but for clear-sky the IMPACT model shows the strongest RF in most of the Northern Hemisphere. The RF in the Southern Hemisphere is generally weak. How clouds affect the RF of the direct aerosol effect depends on a variety 

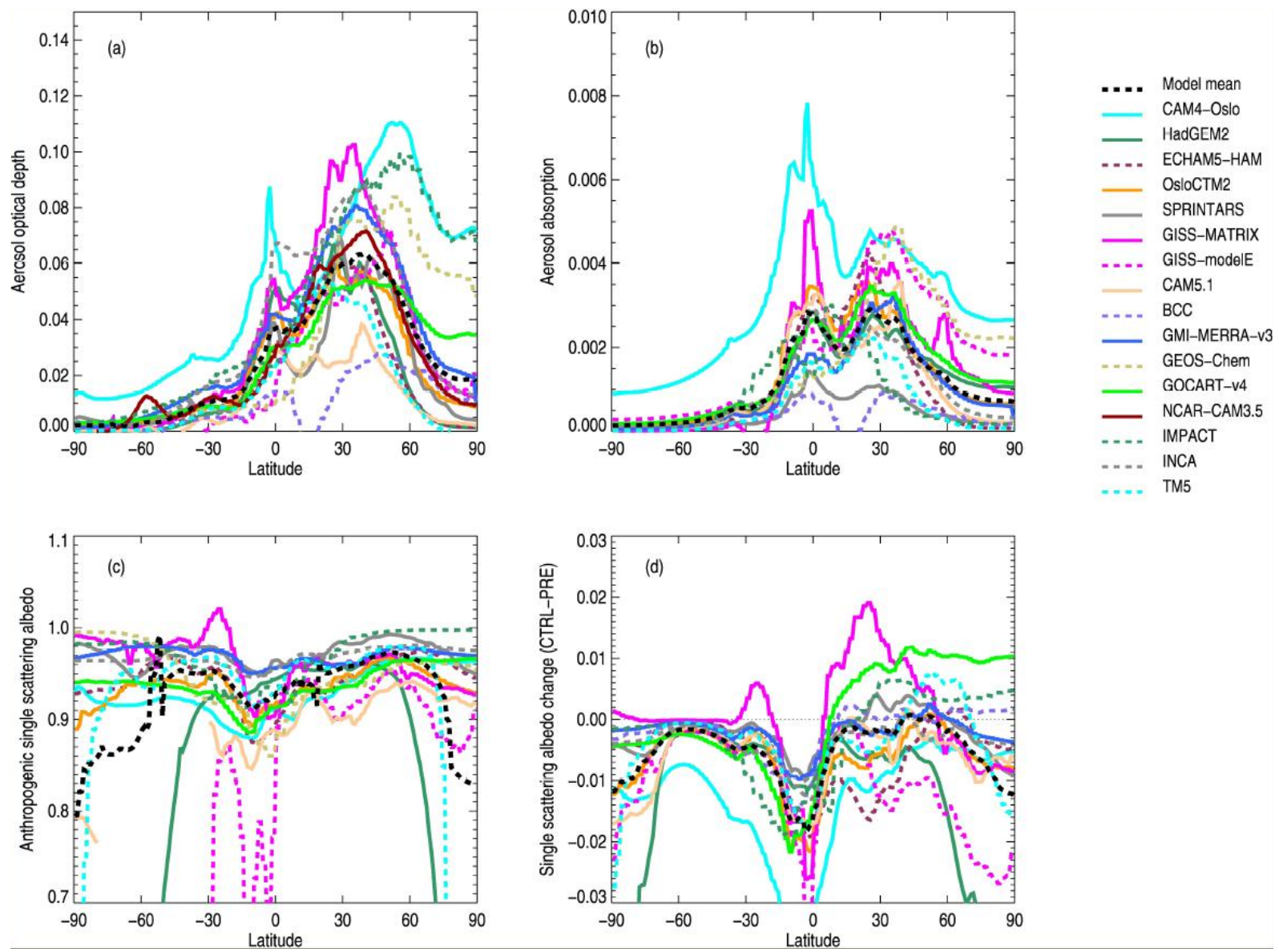

Fig. 3. Anthropogenic AOD (a), anthropogenic AAOD (b), anthropogenic single scattering albedo (c), and change in single scattering albedo from pre-industrial to present conditions (d). All values are taken at $550 \mathrm{~nm}$. Between $80^{\circ} \mathrm{S}$ and $30^{\circ} \mathrm{S}$ the anthropogenic AOD is extremely small for some of the models and anthropogenic single scattering albedo may reach unrealistic values and in such cases values have been removed from the figure.

of factors. Among them are the degree of aerosol absorption, vertical position of aerosols in relation to clouds, and the cloud distribution in general. The all-sky RF is around half in magnitude of the clear sky RF, except for the models with close to zero all sky RF. All models turn over into a positive net RF at high northern latitudes. This is caused by the higher surface and cloud albedo at high latitudes, as can be seen in Fig. 1. The surface and cloud albedo is the main cause of the positive RF since it will be later shown that aerosol optical properties are not a cause for the positive RF (see Fig. 3). CAM4-Oslo has the strongest positive all-sky $\mathrm{RF}$ at high latitudes. This model has more anthropogenic absorbing aerosols at high latitudes than the other models (see Fig. 3). This is partly due to the different CTRL emission data sets, which are for year 2006 and have more biomass burning from forest fires than the 2000 emissions. Assumed emission height of biomass burning (up to $6 \mathrm{~km}$ ) may be another reason. The treatment of convective mixing of aerosols and aerosol precursors probably also leads to somewhat over- estimated aerosol burdens in CAM4-Oslo (see Kirkevåg et al., 2012).

Figure 3 shows the latitudinal variation in the anthropogenic AOD $(550 \mathrm{~nm})$ used in the radiative transfer calculations, anthropogenic absorbing AOD (AAOD) $(550 \mathrm{~nm})$, anthropogenic single scattering albedo $(550 \mathrm{~nm})$, and the change in single scattering albedo $(550 \mathrm{~nm})$ between preindustrial (PRE) and current (CTRL). The anthropogenic AOD in Fig. 3a shows a strong hemispheric difference which is a consistent model characteristic. CAM4-Oslo has the highest and CAM5.1 and BCC the lowest anthropogenic AOD almost at all latitudes. The pattern for the anthropogenic AAOD (Fig. 3b) is rather similar in the models, with two peaks, one around the Equator where biomass burning emissions of $\mathrm{BC}$ are high, and the second around $30^{\circ} \mathrm{N}$, where fossil fuel and biofuel emissions of $\mathrm{BC}$ are high. The range in the anthropogenic single scattering albedo (defined as the ratio of anthropogenic AOD-AAOD and AOD) (Fig. 3c) is large, with most values lying between 0.9 and 1.0 but even lower values than 0.9 seen at high latitudes for a few 
models. The lowest anthropogenic single scattering albedo is simulated near the Equator and can be seen in Fig. $3 b$ to be caused by strong anthropogenic absorption AOD that is not associated with a similar strong maximum in the anthropogenic AOD in Fig. 3a. This pattern is caused by large BB emissions of $\mathrm{BC}$ and $\mathrm{OA}$ in this region. Most models simulate a reduction in the single scattering albedo during the industrial era at all latitudes, except GISS-MATRIX, GOCART, TM5 and IMPACT. The reduction in the single scattering albedo in the majority of the models is due to stronger growth in absorbing aerosol (BC) than scattering aerosols relative to pre-industrial distribution of absorbing and scattering aerosols. GOCART has an increase in the single scattering albedo in the $\mathrm{NH}$ due to low single scattering albedo in the PRE simulation compared to most of the other models. IMPACT shows a weaker increase in single scattering albedo than GOCART, but still positive in the NH. As will be shown later this model has a much larger anthropogenic influenced SOA than the other models, which is likely the cause of the increase in single scattering albedo.

Table 3 summarizes the global and annual mean values for RF, anthropogenic AOD, anthropogenic absorption AOD (AAOD), atmospheric absorption, anthropogenic single scattering albedo, and cloud fraction. The anthropogenic AOD has a mean of 0.030, which is slightly higher than the Schulz et al. (2006) value of 0.029. A main reason for this small increase is likely the inclusion of additional aerosol components in this experiment. The anthropogenic AAOD of 0.0015 is lower than the value of 0.0019 for AAOD attributed to BC in Schulz et al. (2006). However, here it should be mentioned that some of the models in this experiment include absorption by OA which is non-negligible at $550 \mathrm{~nm}$ and thus the anthropogenic AAOD is not solely due to BC. A main reason for the lower AAOD compared to Schulz et al. (2006) is likely due to the much smaller anthropogenic $\mathrm{BB}$ emissions of $\mathrm{BC}$ in a majority of the models using the Lamarque et al. (2010) data. Figure 4 shows the model simulated global and annual mean total RF and the RF for the six aerosol components. The simulated mean RF for the DAE is $-0.27 \mathrm{Wm}^{-2}$ which is stronger negative than the mean of $-0.22 \mathrm{Wm}^{-2}$ found in Schulz et al. (2006). A stronger negative RF of the DAE in this experiment than in Schulz et al. (2006) is in accordance with the stronger AOD and weaker AAOD as noted above. It can also be noted that the models in this experiment have lower global and annual mean cloud cover (mean of $57 \%$ for the 13 models reporting cloud cover) than in the models in Schulz et al. (2006) (mean of $63 \%$ ). As shown in many previous studies of the DAE the total RF consists of aerosol components causing negative RF and positive RF. Figure 4 shows clearly that this balance varies substantially between the models. Further, it shows that some models have weak RF for the aerosol components (CAM5 and BCC) whereas other models have stronger aerosol component RF (CAM4-Oslo, OsloCTM2 and GMI).

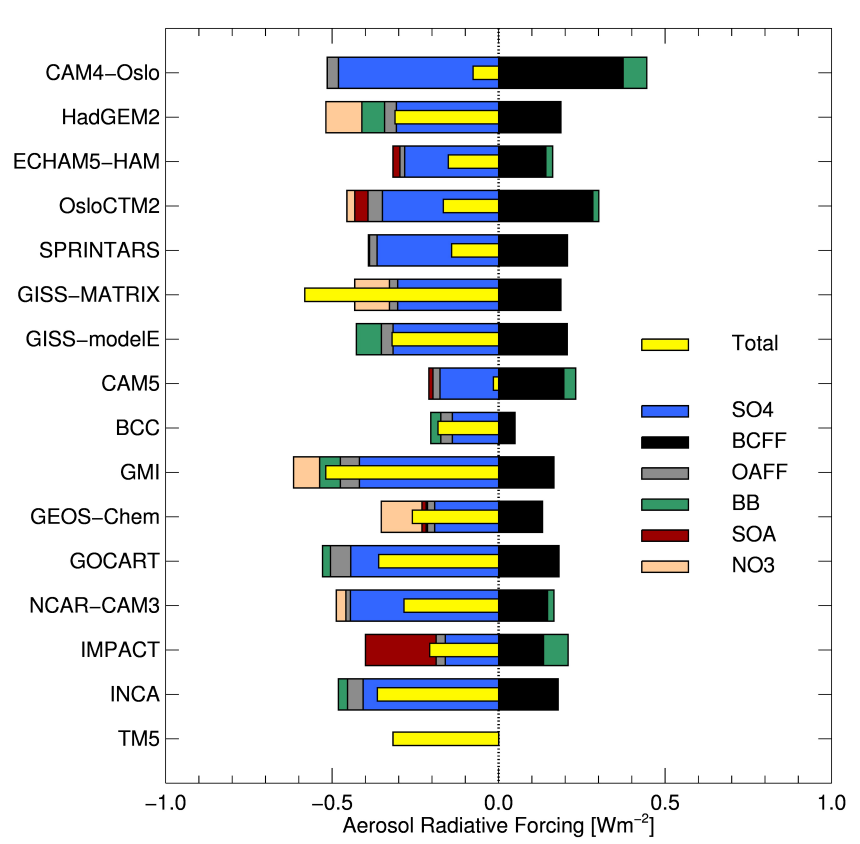

Fig. 4. Radiative forcing from the six components, overlain with the (unmodified) model total forcing (yellow bars).

Not all models have all six aerosol components included. Figure 5 shows the total RF where modifications for missing aerosol components have been taken into account. We calculate the mean of each aerosol component from all models that treat it, then add that mean to the total RF for each component that an individual model doesn't treat. Since the missing aerosol components in the models are predominantly scattering aerosols (nitrate, SOA, and in some few cases BB aerosols), the modification leads to stronger negative RF for all models with modification. The mean RF of the DAE changes from $-0.27 \mathrm{Wm}^{-2}$ to $-0.32 \mathrm{Wm}^{-2}$ with the aerosol component modification.

Table 3 also shows the normalized clear sky RF (NRF, clear sky RF divided by AOD), which ranges from $-17 \mathrm{Wm}^{-2}$ to $-76 \mathrm{Wm}^{-2}$ with a mean of $-27 \mathrm{Wm}^{-2}$. The NRF depends on a variety of factors such as spatial distribution, optical properties, and the vertical profile. The weakening of the DAE RF due to clouds (Schulz et al., 2006) depends on vertical positioning of the aerosols and the clouds (Chand et al., 2009; Liao and Seinfeld, 1998; Samset and Myhre, 2011) as well as the degree of absorption of the aerosols (single scattering albedo) (Haywood and Shine, 1995).

Atmospheric absorption by the aerosols is calculated as the difference between the RF at TOA and radiative effect of aerosols at the surface. Absorbing aerosols such as $\mathrm{BC}$ are the main cause for the atmospheric absorption by the aerosols, but scattering aerosols enhance the absorption by gases in the atmosphere and make a small contribution (Randles et al., 2012; Stier et al., 2012). Figure 6 shows 
Table 3. Global mean anthropogenic value for all-sky and clear sky RF, normalized RF (NRF) with respect to AOD for clear sky, atmospheric absorption, atmospheric absorption divided by AAOD, AOD, anthropogenic fraction of AOD, AAOD, single scattering albedo (SSA), combined natural and anthropogenic change in SSA from PRE simulation to CTRL simulation, and present day cloud fraction (CLT). For NCAR-CAM3 the sum of component forcings is used.

\begin{tabular}{|c|c|c|c|c|c|c|c|c|c|c|c|}
\hline Model & $\begin{array}{l}\text { RF All-sky } \\
{\left[\mathrm{W} \mathrm{m}^{-2}\right]}\end{array}$ & $\begin{array}{l}\text { RF Clear-sky } \\
{\left[\mathrm{W} \mathrm{m}^{-2}\right]}\end{array}$ & $\begin{array}{l}\text { NRF Clear-sky } \\
{\left[\mathrm{W} \mathrm{m}^{-2}\right]}\end{array}$ & $\begin{array}{l}\text { Atm.abs. } \\
{\left[\mathrm{W} \mathrm{m}^{-2}\right]}\end{array}$ & $\begin{array}{l}\text { Atm.abs/AAOD } \\
{\left[\mathrm{W} \mathrm{m}^{-2}\right]}\end{array}$ & $\begin{array}{l}\text { AOD } \\
{[1]}\end{array}$ & $\begin{array}{l}\text { AOD Ant.fr. } \\
{[1]}\end{array}$ & $\begin{array}{l}\text { AAOD } \\
{[1]}\end{array}$ & $\begin{array}{l}\text { SSA } \\
{[1]}\end{array}$ & $\begin{array}{l}\text { dSSA } \\
{[1]}\end{array}$ & $\begin{array}{l}\text { CLT } \\
{[1]}\end{array}$ \\
\hline $\mathrm{BCC}$ & -0.18 & -0.75 & -76.0 & 0.20 & 561 & 0.0099 & 0.138 & 0.0004 & 0.963 & -0.0007 & 0.59 \\
\hline CAM4-Oslo & -0.08 & & & 1.75 & 479 & 0.0527 & 0.345 & 0.0037 & 0.931 & -0.0148 & 0.54 \\
\hline CAM5.1 & -0.016 & -0.35 & -23.6 & 0.69 & 470 & 0.0148 & 0.123 & 0.0015 & 0.901 & -0.0064 & 0.64 \\
\hline GEOS_CHEM & -0.26 & -0.61 & -20.7 & 0.66 & 387 & 0.0293 & 0.231 & 0.0017 & 0.942 & -0.011 & 0.59 \\
\hline GISS-MATRIX & -0.58 & -0.79 & -19.9 & & & 0.0398 & 0.229 & 0.0018 & 0.955 & -0.0005 & 0.65 \\
\hline GISS-modelE & -0.32 & -0.46 & -20.9 & & & 0.0219 & 0.147 & 0.0020 & 0.907 & -0.0096 & 0.65 \\
\hline GMI & -0.52 & -0.91 & -24.7 & 0.49 & 387 & 0.0368 & 0.271 & 0.0013 & 0.965 & -0.0033 & \\
\hline GOCART & -0.36 & -0.58 & -21.8 & 0.73 & 432 & 0.0267 & 0.236 & 0.0017 & 0.937 & 0.0005 & \\
\hline HadGEM2 & -0.31 & -0.72 & -27.2 & 0.61 & 429 & 0.0265 & 0.209 & 0.0014 & 0.947 & -0.0073 & 0.55 \\
\hline IMPACT-Umich & -0.21 & -1.01 & -23.7 & 1.10 & 935 & 0.0428 & 0.325 & 0.0012 & 0.973 & -0.0014 & 0.66 \\
\hline INCA & -0.36 & -0.73 & -17.4 & 0.95 & 723 & 0.0417 & 0.295 & 0.0013 & 0.968 & -0.0046 & 0.47 \\
\hline ЕСНАM5-HAM & -0.15 & -0.44 & -17.8 & & & 0.0244 & 0.218 & 0.0016 & 0.936 & -0.0101 & 0.63 \\
\hline NCAR-CAM3.5 & -0.28 & -0.74 & -24.7 & 0.47 & 360 & 0.0298 & 0.277 & 0.0013 & 0.956 & & \\
\hline OsloCTM2 & -0.17 & -0.69 & -25.0 & 0.82 & 481 & 0.0276 & 0.221 & 0.0017 & 0.9389 & -0.0078 & 0.62 \\
\hline SPRINTARS & -0.14 & -0.71 & -27.4 & 0.85 & 685 & 0.0260 & 0.272 & 0.0012 & 0.952 & -0.0071 & 0.60 \\
\hline TM5 & -0.32 & -0.51 & -24.5 & 0.43 & 492 & 0.0208 & 0.282 & 0.0009 & 0.958 & -0.0054 & 0.25 \\
\hline Mean & -0.27 & -0.67 & -26.8 & 0.75 & 525 & 0.0295 & 0.239 & 0.0015 & 0.946 & -0.0060 & 0.57 \\
\hline Median & -0.26 & -0.71 & -23.7 & 0.69 & 479 & 0.0276 & 0.233 & 0.0015 & 0.952 & -0.0064 & 0.62 \\
\hline Stddev & 0.15 & 0.18 & 14.5 & 0.38 & 165 & 0.011 & 0.064 & 0.0007 & 0.021 & 0.0044 & 0.12 \\
\hline
\end{tabular}

Table 4. Anthropogenic load, mass extinction coefficient (MEC), AOD, RF, normalized RF with respect to burden (NRFB), normalized RF with respect to AOD (NRFA) for sulphate.

\begin{tabular}{lrrrrrr}
\hline Model & $\begin{array}{r}\text { Load } \\
{\left[\mathrm{mg} \mathrm{m}^{-2}\right]}\end{array}$ & $\begin{array}{r}\text { MEC } \\
{\left[\mathrm{m}^{2} \mathrm{~g}^{-1}\right]}\end{array}$ & $\begin{array}{r}\text { AOD } \\
{[1]}\end{array}$ & $\begin{array}{r}\mathrm{RF} \\
{\left[\mathrm{W} \mathrm{m}^{-2}\right]}\end{array}$ & $\begin{array}{r}\text { NRFB } \\
{\left[\mathrm{W} \mathrm{g}^{-1}\right]}\end{array}$ & $\begin{array}{r}\text { NRFA } \\
{\left[\mathrm{W} \mathrm{m}^{-2}\right]}\end{array}$ \\
\hline BCC & 1.29 & 5.4 & 0.0069 & -0.14 & -108 & -20.0 \\
CAM4-Oslo & 2.78 & 12.3 & 0.0342 & -0.48 & -173 & -14.0 \\
CAM5.1 & 1.69 & 5.6 & 0.0095 & -0.18 & -104 & -18.4 \\
GEOS_CHEM & 1.57 & 7.3 & 0.0114 & -0.19 & -123 & -16.8 \\
GISS-MATRIX & 1.54 & & & -0.30 & -196 & \\
GISS-modelE & 1.03 & 38.6 & 0.0398 & -0.32 & -307 & -8.0 \\
GMI & 2.14 & 12.0 & 0.0256 & -0.42 & -195 & -16.3 \\
GOCART & 1.87 & 12.2 & 0.0228 & -0.44 & -238 & -19.5 \\
HadGEM2 & 1.59 & 8.9 & 0.0142 & -0.31 & -193 & -21.7 \\
IMPACT-Umich & 1.42 & 10.3 & 0.0146 & -0.16 & -113 & -11.0 \\
INCA & 2.26 & 12.5 & 0.0283 & -0.41 & -180 & -14.4 \\
MPIHAM & 2.25 & 9.1 & 0.0204 & -0.28 & -125 & -13.8 \\
NCAR-CAM3.5 & 1.27 & 23.2 & 0.0295 & -0.45 & -354 & -15.1 \\
OsloCTM2 & 1.82 & 10.1 & 0.0183 & -0.35 & -192 & -19.0 \\
SPRINTARS & 2.13 & 10.3 & 0.0220 & -0.37 & -172 & -16.6 \\
\hline Mean & 1.78 & 12.7 & 0.0213 & -0.32 & -185 & -16.0 \\
Median & 1.69 & 10.3 & 0.0212 & -0.32 & -180 & -16.5 \\
Stddev & 0.47 & 8.6 & 0.0096 & 0.11 & 71 & 3.7 \\
\hline
\end{tabular}

the atmospheric absorption by anthropogenic aerosols as a function of absorbing AOD. The mean atmospheric absorption (see Table 3 ) is $0.75 \mathrm{Wm}^{-2}$, which is weaker than the $0.82 \mathrm{Wm}^{-2}$ reported in Schulz et al. (2006). The normalized values (atmospheric absorption divided by absorbing AOD) are shown on the figure. Normalized values range from $360 \mathrm{Wm}^{-2}$ to $935 \mathrm{Wm}^{-2}$ with a mean of $525 \mathrm{Wm}^{-2}$ and the median $10 \%$ lower. Some of the models with lowest anthropogenic atmospheric absorption have the largest deviation from the mean of the normalized values. The correlation between anthropogenic absorption AOD and atmospheric absorption is 0.73 for the 12 models available for this part of the study. IMPACT has high atmospheric absorption mainly, as discussed above, due to a large fraction of SOA that absorbs 


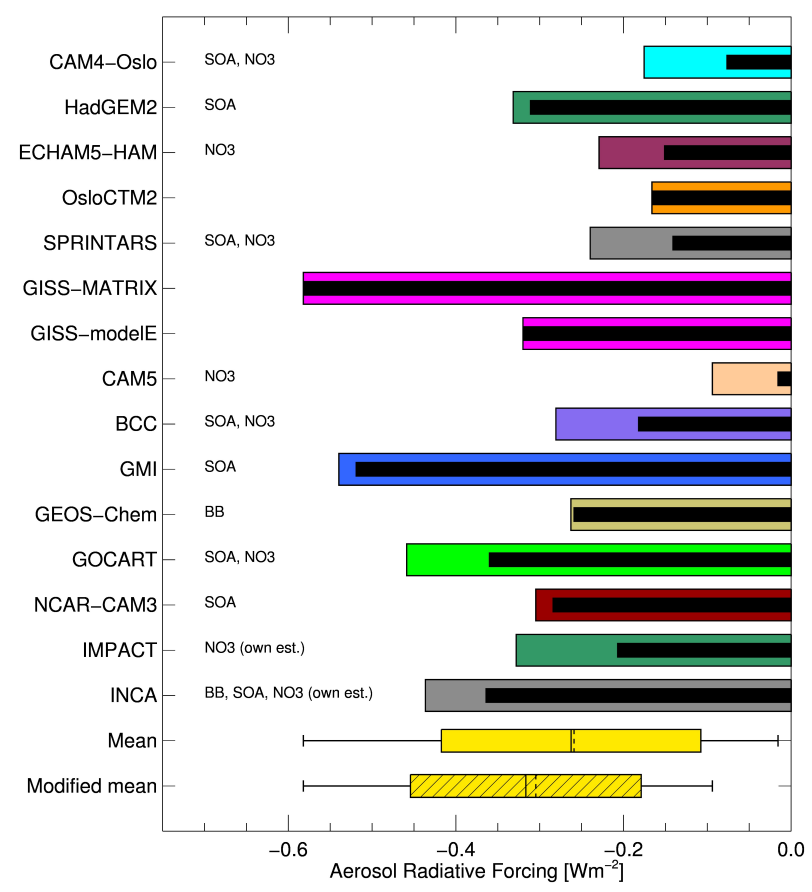

Fig. 5. Model total RFs. Black bars show the bare modelled forcing, the colored bars show the forcing modified for untreated components (see text for details). The yellow bar shows the AeroCom mean of the total RF of DAE. Solid lines inside the boxes show the model mean, dashed lines show the median. The boxes indicate one standard deviation, while the whiskers indicate the max and min of the distribution. The yellow shaded bar shows the AeroCom mean when aerosol component adjustment is made for missing aerosol components.

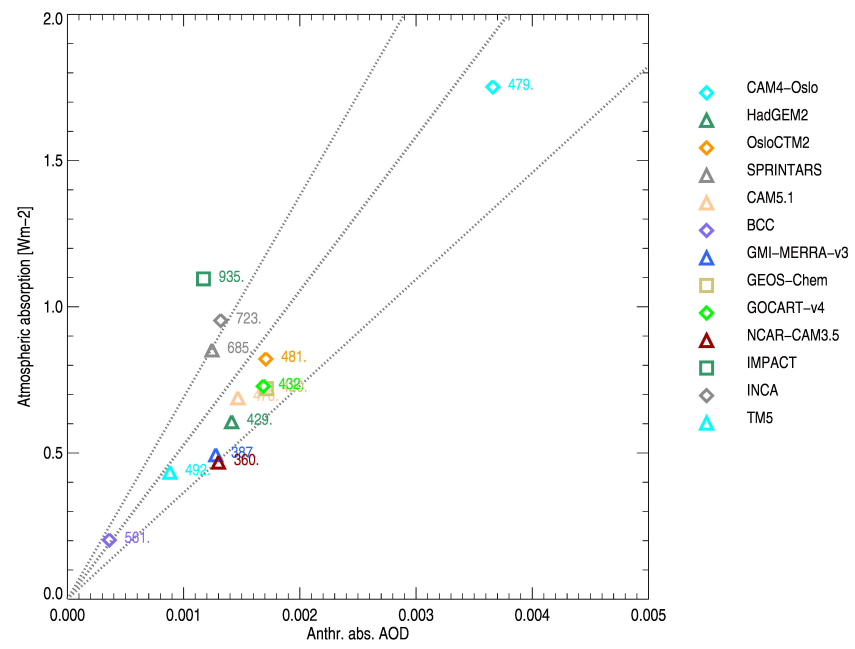

Fig. 6. Correlation between anthropogenic absorption AOD and atmospheric absorption. Numbers show ratio AtmAbs/AAOD, the lines indicate the mean and one standard deviation of this ratio. $R^{2}=0.73$

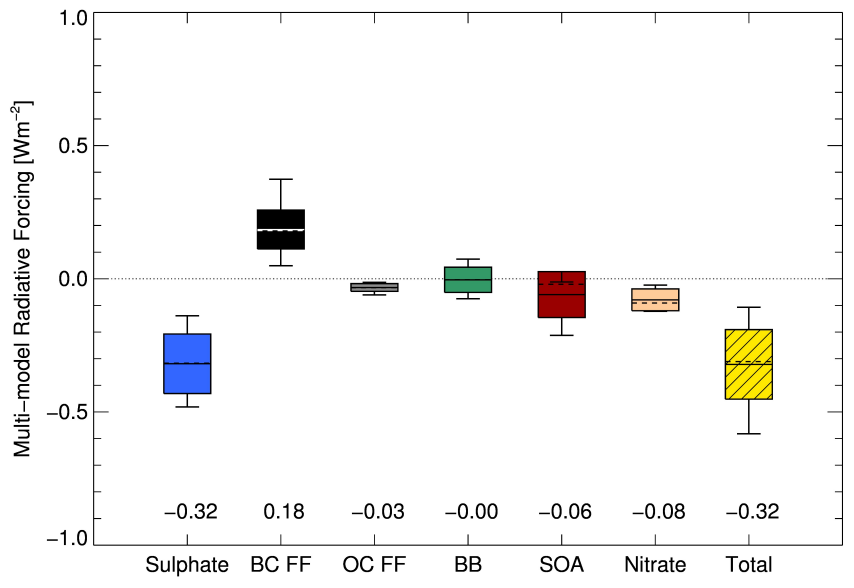

Fig. 7. Component and total RF. Total RF has been modified for missing components in individual models. Solid lines inside the boxes show the model mean, dashed lines show the median. The boxes indicate one standard deviation, while the whiskers indicate the max and min of the distribution.

at short wavelengths, while the absorption is much weaker at $550 \mathrm{~nm}$ which is the reported wavelength for absorption AOD. This leads to the strongest normalized atmospheric absorption of $935 \mathrm{Wm}^{-2}$ for IMPACT. The mean of the anthropogenic fraction of AOD (Table 3 ) is $24 \%$, slightly smaller than in Schulz et al. (2006), where a different preindustrial year (here 1850 instead of 1750) is one contributor to this reduction. Half of the models are close to the mean anthropogenic fraction, whereas two of the models have quite low anthropogenic fractions of $12-14 \%$ and one has $35 \%$.

Figure 7 summarizes the component and aerosol component modified total RFs and their intermodel variability. Model means are shown as solid lines in the middle of the boxes, median values as dashed lines. The boxes indicate one standard deviation, and the bars show the maximum and minimum single values.

In the following sections we discuss the individual aerosol components in detail, highlighting model results that deviate significantly from the mean.

\subsection{RF of sulphate}

The RF of the direct aerosol effect of sulphate is shown in Fig. 4 for all models. In addition Figure 7 shows the mean, median, standard deviation and the range for sulphate aerosols and for other aerosol components. Table 4 summarizes the aerosol burden, mass extinction coefficient (MEC) $(550 \mathrm{~nm}), \mathrm{AOD}(550 \mathrm{~nm}), \mathrm{RF}$, and NRF with respect to both burden and AOD. The mean RF of sulphate from the AeroCom Phase II models of $-0.32 \mathrm{Wm}^{-2}$ is weaker than the mean of AeroCom Phase I models of $-0.35 \mathrm{Wm}^{-2}$ in Schulz et al. (2006). The range in RF is very similar in the two AeroCom DAE experiments. The global mean MEC is calculated as the ratio of global mean AOD to global mean burden. The 

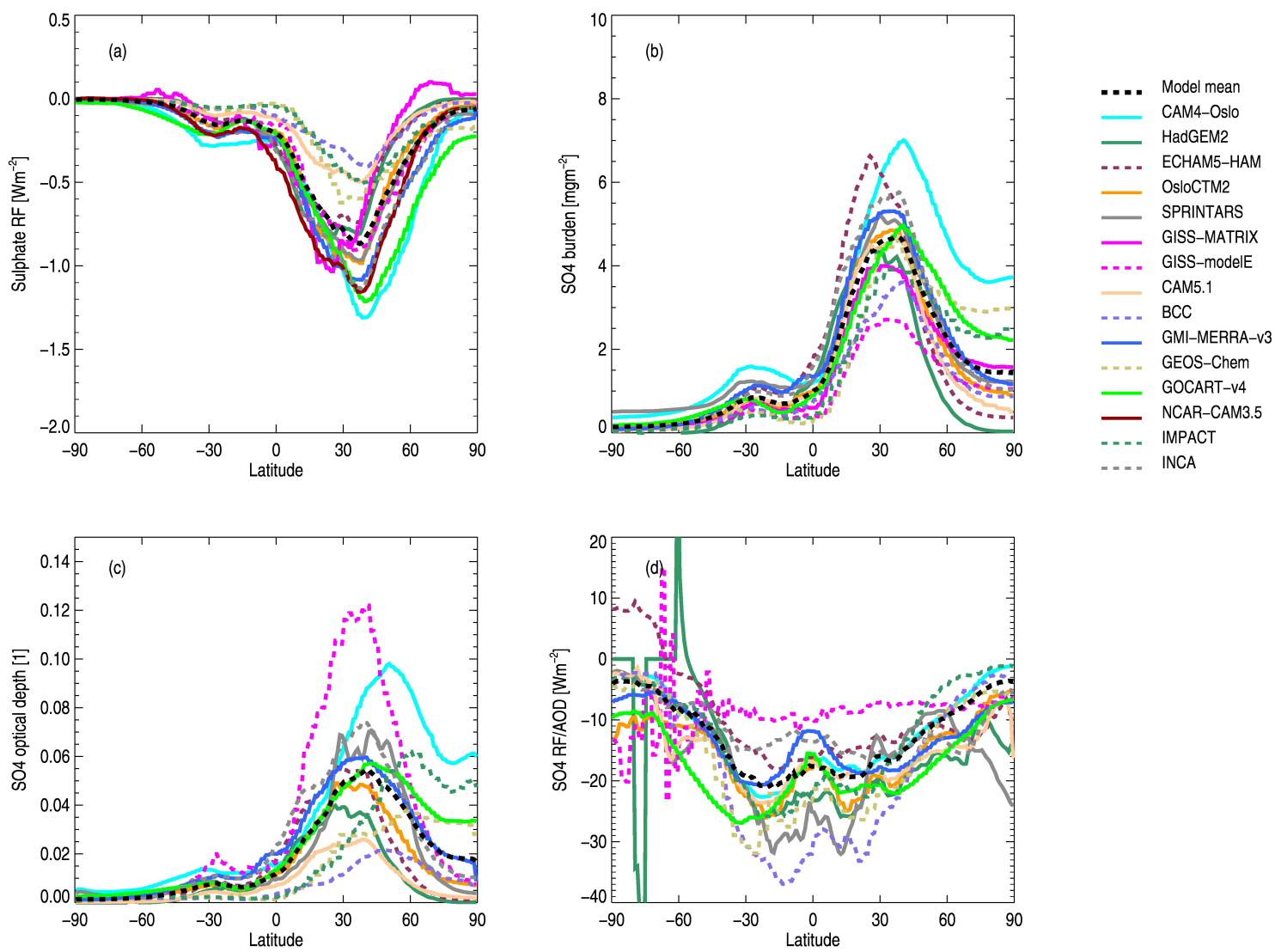

Fig. 8. Zonal mean $\mathrm{SO}_{4} \mathrm{RF}$ (a), burden (b), AOD at $550 \mathrm{~nm}$ (c), normalized RF with respect to AOD (NRF(A)) (d).

Table 5. Same as Table 4 for BC from FF and BF emissions.

\begin{tabular}{lrrrrrr}
\hline Model & $\begin{array}{r}\text { Load } \\
{\left[\mathrm{mg} \mathrm{m}^{-2}\right]}\end{array}$ & $\begin{array}{r}\text { MEC } \\
{\left[\mathrm{m}^{2} \mathrm{~g}^{-1}\right]}\end{array}$ & $\begin{array}{r}\text { AOD } \\
{[1]}\end{array}$ & $\begin{array}{r}\mathrm{RF} \\
{\left[\mathrm{W} \mathrm{m}^{-2}\right]}\end{array}$ & $\begin{array}{r}\text { NRFB } \\
{\left[\mathrm{W} \mathrm{g}^{-1}\right]}\end{array}$ & $\begin{array}{r}\text { NRFA } \\
{\left[\mathrm{W} \mathrm{m}^{-2}\right]}\end{array}$ \\
\hline BCC & 0.08 & 4.2 & 0.0003 & 0.05 & 650 & 155.1 \\
CAM4-Oslo & 0.21 & 8.2 & 0.0017 & 0.37 & 1763 & 216.0 \\
CAM5.1 & 0.07 & 18.6 & 0.0014 & 0.20 & 2661 & 143.3 \\
GEOS_CHEM & 0.12 & 8.2 & 0.0010 & 0.13 & 1067 & 130.0 \\
GISS-MATRIX & 0.08 & & & 0.19 & 2484 & \\
GISS-modelE & 0.16 & 13.8 & 0.0023 & 0.21 & 1253 & 90.9 \\
GMI & 0.14 & 12.0 & 0.0017 & 0.17 & 1208 & 100.4 \\
GOCART & 0.21 & 10.4 & 0.0021 & 0.18 & 874 & 84.3 \\
HadGEM2 & 0.31 & 5.4 & 0.0016 & 0.19 & 612 & 114.1 \\
IMPACT-Umich & 0.09 & 14.0 & 0.0013 & 0.14 & 1467 & 104.6 \\
INCA & 0.15 & 9.5 & 0.0015 & 0.18 & 1160 & 122.5 \\
MPIHAM & 0.10 & 11.2 & 0.0011 & 0.14 & 1453 & 130.2 \\
NCAR-CAM3.5 & 0.11 & & & 0.15 & 1364 & \\
OsloCTM2 & 0.13 & 13.0 & 0.0017 & 0.28 & 2161 & 166.4 \\
SPRINTARS & 0.16 & 7.7 & 0.0012 & 0.21 & 1322 & 170.8 \\
\hline Mean & 0.14 & 10.5 & 0.0015 & 0.18 & 1438 & 133.0 \\
Median & 0.14 & 10.4 & 0.0015 & 0.18 & 1322 & 130.0 \\
Stddev & 0.07 & 3.9 & 0.0005 & 0.07 & 630 & 37.1 \\
\hline
\end{tabular}



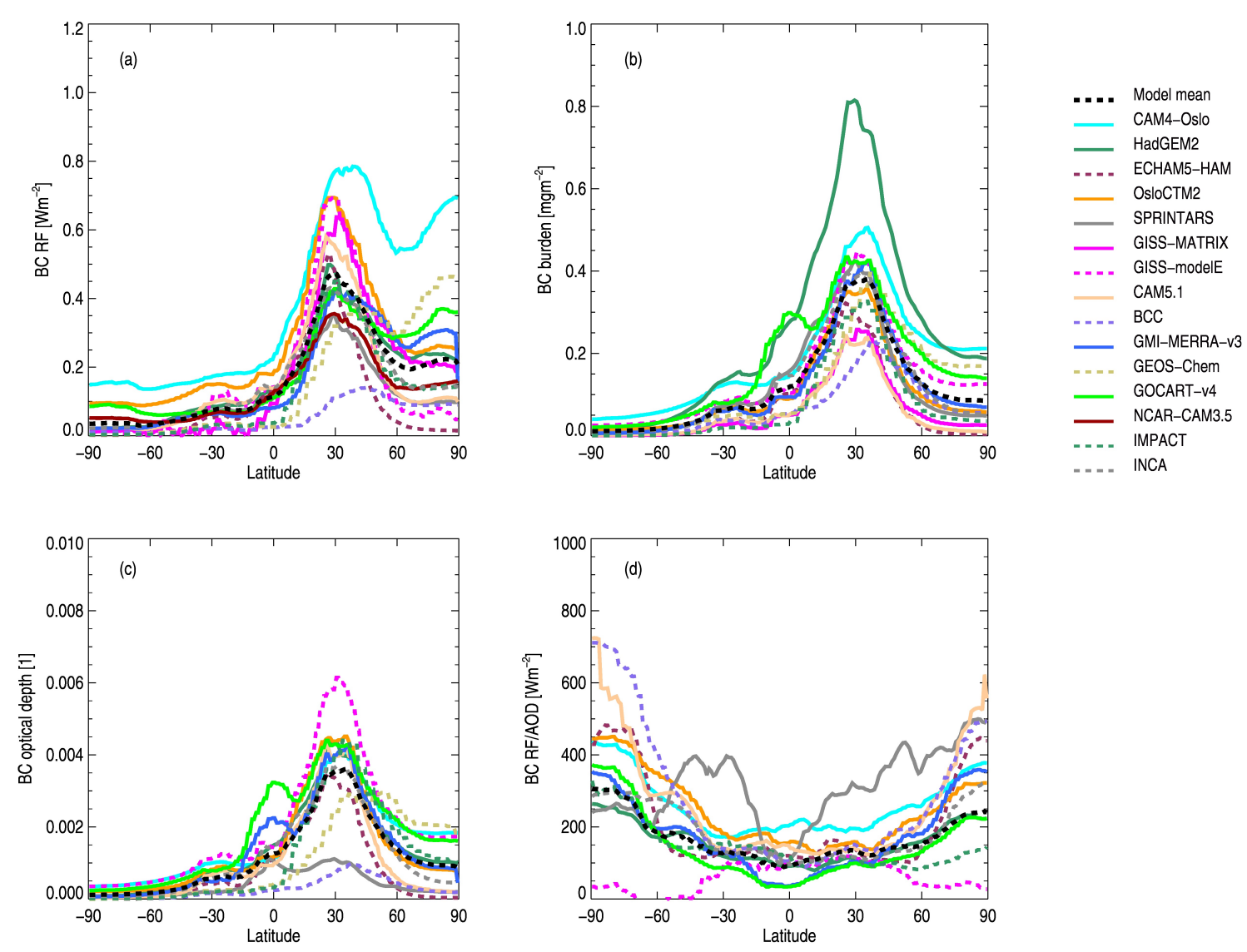

Fig. 9. Zonal mean BC RF (a), burden (b), AOD at $550 \mathrm{~nm}$ (c), NRF(A) (d).

MEC depends on various factors, where growth by water uptake for sulphate aerosols is a major cause of the difference between the models. To illustrate the importance of water uptake, the MEC in OsloCTM2 is $4.0 \mathrm{~m}^{2} \mathrm{~g}^{-1}$ for low relative humidity (below $30 \%$ ) and is $10.1 \mathrm{~m}^{2} \mathrm{~g}^{-1}$ as a global mean with ambient relative humidity. The mean of the MEC is $12.7 \mathrm{~m}^{2} \mathrm{~g}^{-1}$, but also without the two models with very high MEC (NCAR-CAM3.5 and GISS modelE ) the MEC is $9.7 \mathrm{~m}^{2} \mathrm{~g}^{-1}$ and $7 \%$ higher than in Schulz et al. (2006). The weaker normalized RF with respect to AOD and stronger with respect to burden than in Schulz et al. (2006) could be a result of sulphate at generally lower altitudes, but other factors could contribute.

Figure 8 shows the latitudinal variation in RF, burden, AOD, NRF (with respect to AOD) for sulphate. All models have a maximum in the burden at around $30^{\circ} \mathrm{N}$ with a large difference in the magnitude. The difference in the magnitude of the burden is particularly large at high northern latitudes and is likely linked to transport and scavenging problems in the models (Rasch et al., 2000). The difference in RF of sulphate at high latitudes is not as evident as for the burden (and AOD), since NRF at high latitudes is weak due to the high surface albedo, and some of the models with strongest bur- den (and AOD) have weak NRF. The RF of sulphate is very weak in the Southern Hemisphere.

\subsection{RF of BC}

In Fig. 9 the latitudinal variation is shown for RF, burden, AOD, NRF (with respect to AOD) for BC from FF and BF emissions. Global numbers are shown in Table 5. The importance of surface and cloud albedo is evident in the NRF for BC, especially if it is compared to NRF for sulphate in Fig. 8d, which weakens (for a majority of the models) rather than strengthens over the poles as for $\mathrm{BC}$. The much stronger NRF at high latitudes for BC than sulphate and the relatively large range in burden at high latitudes are also clearly evident for the RF. Schulz et al. (2006) showed the latitudinal variation in burden of $\mathrm{BC}$ (total and not only FF and $\mathrm{BF}$ as in Fig. 9b). There is no indication of a reduced range in the $\mathrm{BC}$ burden among the AeroCom models from Phase I to Phase II. For the maximum in RF at around $30^{\circ} \mathrm{N}$ there is almost an order of magnitude difference between the model with strongest RF (CAM4-Oslo) and the model with the weakest RF (BCC). The model differences in the $\mathrm{NRF}$ are larger for $\mathrm{BC}$ than for sulphate, and main reason for this is likely a strong dependence on altitude of BC and 
Table 6. Same as Table 4 for OA from FF and BF emissions.

\begin{tabular}{lrrrrrr}
\hline Model & $\begin{array}{r}\text { Load } \\
{\left[\mathrm{mg} \mathrm{m}^{-2}\right]}\end{array}$ & $\begin{array}{r}\text { MEC } \\
{\left[\mathrm{m}^{2} \mathrm{~g}^{-1}\right]}\end{array}$ & $\begin{array}{r}\mathrm{AOD} \\
{[1]}\end{array}$ & $\begin{array}{r}\mathrm{RF} \\
{\left[\mathrm{W} \mathrm{m}^{-2}\right]}\end{array}$ & $\begin{array}{r}\mathrm{NRFB} \\
{\left[\mathrm{W} \mathrm{g}^{-1}\right]}\end{array}$ & $\begin{array}{r}\text { NRFA } \\
{\left[\mathrm{W} \mathrm{m}^{-2}\right]}\end{array}$ \\
\hline BCC & 0.35 & 3.7 & 0.0013 & -0.03 & -97 & -26.3 \\
CAM4-Oslo & 0.28 & 5.8 & 0.0017 & -0.03 & -118 & -20.1 \\
CAM5.1 & 0.31 & 4.6 & 0.0014 & -0.02 & -69 & -15.0 \\
GEOS_CHEM & 0.23 & 4.9 & 0.0011 & -0.02 & -95 & -19.4 \\
GISS-MATRIX & 0.19 & & & -0.02 & -129 & \\
GISS-modelE & 0.46 & 6.1 & 0.0028 & -0.03 & -76 & -12.4 \\
GMI & 0.30 & 6.6 & 0.0020 & -0.06 & -189 & -28.5 \\
GOCART & 0.42 & 4.9 & 0.0021 & -0.06 & -144 & -29.4 \\
HadGEM2 & 0.24 & 7.0 & 0.0017 & -0.04 & -145 & -20.6 \\
IMPACT-Umich & 0.20 & 14.1 & 0.0028 & -0.03 & -141 & -10.0 \\
INCA & 0.62 & 7.5 & 0.0046 & -0.05 & -76 & -10.1 \\
MPIHAM & 0.35 & 1.6 & 0.0006 & -0.01 & -41 & -25.0 \\
NCAR-CAM3.5 & 0.21 & & & -0.01 & -48 & \\
OsloCTM2 & 0.26 & 6.6 & 0.0017 & -0.04 & -165 & -25.1 \\
SPRINTARS & 0.22 & & & -0.02 & -102 & \\
\hline Mean & 0.32 & 6.1 & 0.0020 & -0.03 & -113 & -20.2 \\
Median & 0.30 & 6.1 & 0.0017 & -0.03 & -102 & -20.1 \\
Stddev & 0.12 & 3.0 & 0.0010 & 0.01 & 41 & 6.9 \\
\hline
\end{tabular}

variations in absorbing properties of BC (Samset and Myhre, 2011; Zarzycki and Bond, 2010). The model mean mass extinction coefficient is $10.5 \mathrm{~m}^{2} \mathrm{~g}^{-1}$. Unfortunately the model mass absorption coefficient for BC from FF and BF emissions was not diagnosed. Based on observations, Bond et al. (2006) recommend a mass absorption coefficient (MAC) of around $7.5 \mathrm{~m}^{2} \mathrm{~g}^{-1}$ for fresh BC particles and $50 \%$ higher for aged BC. Jacobson (2012) and Chung et al. (2012) use higher absorption enhancement factors. As the single scattering albedo for $\mathrm{BC}$ often is in the range of 0.2 to 0.3 (Bond and Bergstrom, 2006), the BC MEC should be around $25 \%$ higher than the MAC, implying the models underestimate the MEC and MAC. The low MEC for a few of the models is the cause of the generally low mean MEC; but half of the models have MEC according to the recommendations. Internal mixing of $\mathrm{BC}$ with other aerosol components increases the absorption, so simulating sufficiently high MEC requires representing internal mixing of $\mathrm{BC}$ and its effects on absorption. The difference in MEC for models using internal mixture $\left(12.1 \mathrm{~m}^{2} \mathrm{~g}^{-1}\right)$ is on average $34 \%$ higher than for models assuming external mixture $\left(9.1 \mathrm{~m}^{2} \mathrm{~g}^{-1}\right)$. However, recent work has questioned the importance of the enhancement of MEC from internal mixing, at least in certain regions (Cappa et al., 2012).

The model mean global average burden of $\mathrm{BC}$ is 0.14 $\mathrm{mg} \mathrm{m}^{-2}$ and a RF of $0.18 \mathrm{Wm}^{-2}$. The RF estimate is similar to the IPCC AR4 estimate, but much lower than Ramanathan and Carmichael (2008). However, the estimates here and in IPCC AR4 (Forster et al., 2007) are solely from FF and BF, whereas Ramanathan and Carmichael (2008) included also
$\mathrm{BC}$ from $\mathrm{BB}$ emissions and estimate forcing for all $\mathrm{BC}$, not just anthropogenic. The spread in NRF with respect to burden is larger than in NRF with respect to AOD due to variations in MEC included in the former. For the two NRF measures the model difference is shown to arise from differences in the vertical profile of BC (Samset et al., 2012), host model difference (Stier et al., 2012) and likely differences in optical properties, especially the single scattering albedo of BC.

\subsection{RF of OA}

The RF of primary OA from $\mathrm{FF}$ and $\mathrm{BF}$ is weak and has a mean of $-0.03 \mathrm{Wm}^{-2}$. The RF together with burden, MEC, AOD and NRF are shown in Table 6. Primary OA from biomass burning and SOA are described in separate sections below. The burden of OA is on average about $20 \%$ of the sulphate burden; however, this fraction varies between the models. RF from primary OA from FF and BF is around $10 \%$ of the sulphate RF, and thus the NRF with respect to burden for $\mathrm{OA}$ is much weaker than for sulphate. One main reason for this is the much smaller water uptake for OA. This is also reflected in the MEC. Due to the smaller water uptake for OA compared to sulphate the particles are smaller, leading to a larger Ångstrøm exponent and a stronger NRF with respect to AOD. Compared to BC from FF, OA has a lower burden in the Arctic (see Fig. 10). Combined with the weak NRF in the Arctic for scattering aerosols, this causes the quite weak $\mathrm{RF}$ from OA in this region seen in Fig. 10. 

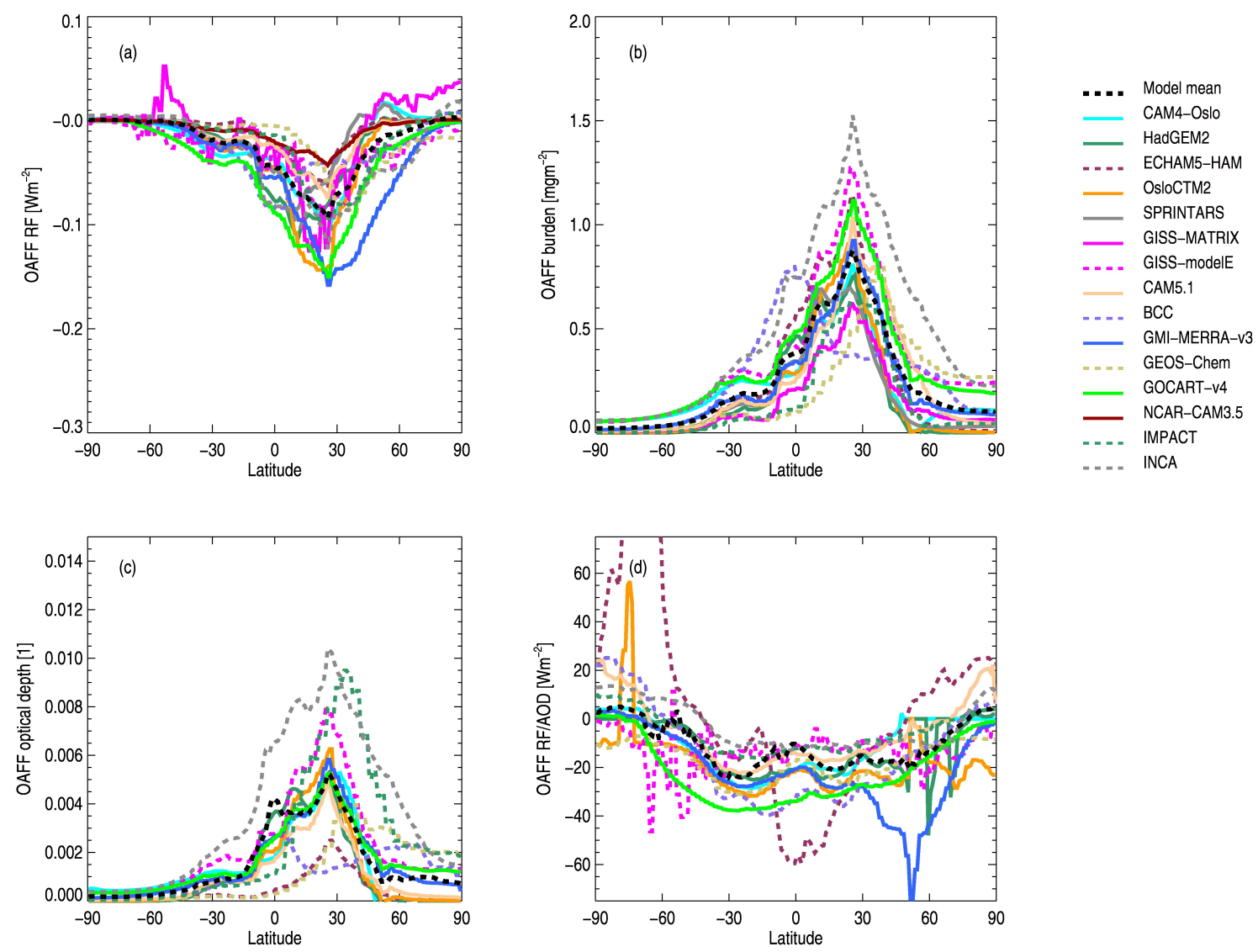

Fig. 10. Zonal mean OAFF RF (a), burden (b), AOD at $550 \mathrm{~nm}$ (c), NRF(A) (d).

Table 7. Same as Table 4 for SOA.

\begin{tabular}{lrrrrrr}
\hline Model & $\begin{array}{r}\text { Load } \\
{\left[\mathrm{mg} \mathrm{m}^{-2}\right]}\end{array}$ & $\begin{array}{r}\text { MEC } \\
{\left[\mathrm{m}^{2} \mathrm{~g}^{-1}\right]}\end{array}$ & $\begin{array}{r}\text { AOD } \\
{[1]}\end{array}$ & $\begin{array}{r}\mathrm{RF} \\
{\left[\mathrm{W} \mathrm{m}^{-2}\right]}\end{array}$ & $\begin{array}{r}\text { NRFB } \\
{\left[\mathrm{W} \mathrm{g}^{-1}\right]}\end{array}$ & $\begin{array}{r}\text { NRFA } \\
{\left[\mathrm{W} \mathrm{m}^{-2}\right]}\end{array}$ \\
\hline CAM5.1 & 0.27 & 8.0 & 0.0022 & -0.01 & -45 & -5.6 \\
GEOS_CHEM & 0.27 & 2.4 & 0.0006 & -0.01 & -45 & -19.0 \\
GISS-modelE & 0.090 & 6.3 & 0.0006 & & & \\
IMPACT-Umich & 0.97 & 18.9 & 0.0184 & -0.21 & -218 & -11.5 \\
MPIHAM & 0.15 & 10.9 & 0.0016 & -0.02 & -139 & -12.8 \\
OsloCTM2 & 0.25 & 6.5 & 0.0016 & -0.04 & -161 & -24.6 \\
\hline Mean & 0.33 & 8.8 & 0.0042 & -0.06 & -122 & -14.7 \\
Median & 0.27 & 8.0 & 0.0016 & -0.02 & -139 & -12.8 \\
Stddev & 0.32 & 5.7 & 0.0070 & 0.09 & 76 & 7.3 \\
\hline
\end{tabular}

Another cause for the differences in NRF between the models as well as between sulphate and OA are differences in the single scattering albedo for OA. Several models have single scattering albedo for $\mathrm{OA}$ at $550 \mathrm{~nm}$ at 0.96 with increasing values for higher relative humidity. Some OA components have absorption at short solar wavelength with a reduction in the absorption with wavelength stronger than for BC (Jacobson, 2012; Kanakidou et al., 2005). Uncertainties in the refractive indexes and thus absorption for OA are large.
However, some of the major components of OA do not absorb (Kanakidou et al., 2005). OsloCTM2 has among the strongest RF for $\mathrm{OA}$ from $\mathrm{FF}$ and $\mathrm{BF}$ emissions and uses pure scattering OA aerosols. One additional simulation was performed with OsloCTM2 using refractive indexes for OA as in CAM4-Oslo, resulting in a $25 \%$ weakening in the RF of $\mathrm{OA}$ from $\mathrm{FF}$ and $\mathrm{BF}$ emissions. In the INCA model a larger effect was found when applying pure scattering OA instead 

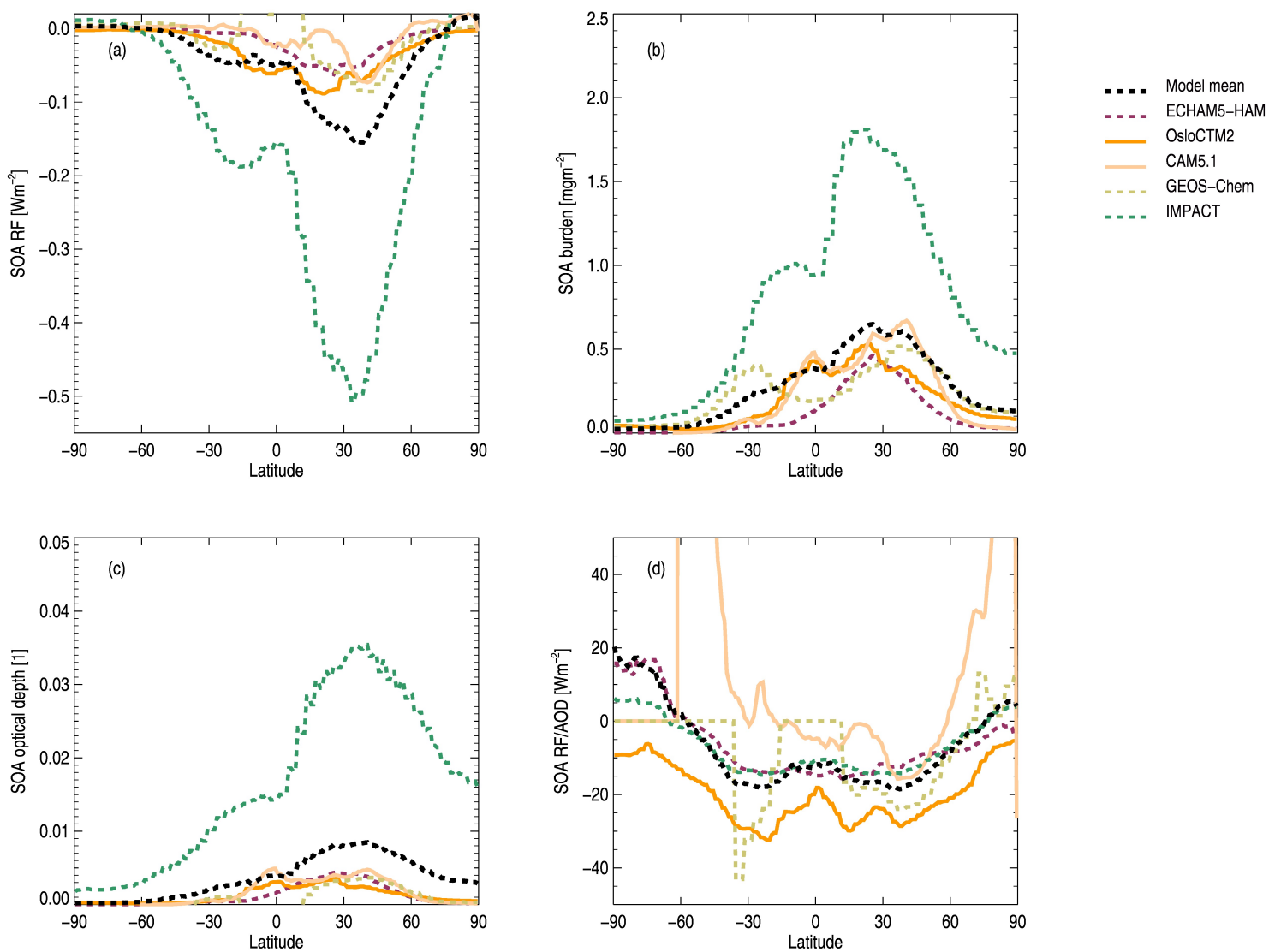

Fig. 11. Zonal mean SOA RF (a), burden (b), AOD at $550 \mathrm{~nm}$ (c), NRF(A) (d).

Table 8. Same as Table 4 for nitrate.

\begin{tabular}{lrrrrrr}
\hline Model & $\begin{array}{r}\text { Load } \\
{\left[\mathrm{mg} \mathrm{m}^{-2}\right]}\end{array}$ & $\begin{array}{r}\text { MEC } \\
{\left[\mathrm{m}^{2} \mathrm{~g}^{-1}\right]}\end{array}$ & $\begin{array}{r}\text { AOD } \\
{[1]}\end{array}$ & $\begin{array}{r}\mathrm{RF} \\
{\left[\mathrm{W} \mathrm{m}^{-2}\right]}\end{array}$ & $\begin{array}{r}\text { NRFB } \\
{\left[\mathrm{W} \mathrm{g}^{-1}\right]}\end{array}$ & $\begin{array}{r}\text { NRFA } \\
{\left[\mathrm{W} \mathrm{m}^{-2}\right]}\end{array}$ \\
\hline GEOS_CHEM & 0.90 & 7.4 & 0.0067 & -0.12 & -136 & -18.4 \\
GISS-MATRIX & 0.44 & & & -0.10 & -240 & \\
GMI & 0.76 & 8.0 & 0.0061 & -0.08 & -103 & -12.9 \\
HadGEM2 & 0.44 & 11.8 & 0.0051 & -0.11 & -249 & -21.1 \\
IMPACT-Umich & 0.78 & 11.2 & 0.0088 & -0.12 & -155 & -13.8 \\
INCA & 0.44 & & & -0.05 & -110 & \\
NCAR-CAM3.5 & 0.32 & 6.3 & 0.002 & -0.03 & -91 & -14.5 \\
OsloCTM2 & 0.14 & 10.8 & 0.0015 & -0.02 & -173 & -16.0 \\
\hline Mean & 0.56 & 9.8 & 0.0056 & -0.08 & -166 & -16.4 \\
Median & 0.44 & 10.8 & 0.0061 & -0.08 & -155 & -16.0 \\
Stddev & 0.27 & 2.0 & 0.0027 & 0.04 & 59 & 3.4 \\
\hline
\end{tabular}

of their standard simulation, resulting in a $72 \%$ enhancement in the RF of OA from FF and BF emissions.

\subsection{RF SOA}

Five models have explicitly performed RF simulations for SOA; the two GISS-models have SOA included in the total DAE simulations and some information is available for
GISS-modelE. The uncertainties in the modelling of SOA are large (Spracklen et al., 2011), and thus it is not surprising that we find a huge range in the burden of anthropogenic SOA from 0.09 to $0.97 \mathrm{mg} \mathrm{m}^{-2}$ (see Table 7). The burden in IMPACT-Umich is substantially higher than the other models. Figure 11 shows that burden of SOA has a larger fraction around the Equator than for the other aerosol 
Table 9. Same as Table 4 for combined OA and BC from BB emissions.

\begin{tabular}{lrrrrrr}
\hline Model & $\begin{array}{r}\text { Load } \\
{\left[\mathrm{mg} \mathrm{m}^{-2}\right]}\end{array}$ & $\begin{array}{r}\text { MEC } \\
{\left[\mathrm{m}^{2} \mathrm{~g}^{-1}\right]}\end{array}$ & $\begin{array}{r}\text { AOD } \\
{[1]}\end{array}$ & $\begin{array}{r}\mathrm{RF} \\
{\left[\mathrm{W} \mathrm{m}^{-2}\right]}\end{array}$ & $\begin{array}{r}\text { NRFB } \\
{\left[\mathrm{W} \mathrm{g}^{-1}\right]}\end{array}$ & $\begin{array}{r}\text { NRFA } \\
{\left[\mathrm{W} \mathrm{m}^{-2}\right]}\end{array}$ \\
\hline BCC & 0.46 & 3.9 & 0.0018 & -0.03 & -65 & -16.8 \\
CAM4-Oslo & 2.96 & 5.4 & 0.0159 & 0.07 & 24 & 4.5 \\
CAM5.1 & 0.24 & 7.0 & 0.0017 & 0.04 & 145 & 20.7 \\
GEOS_CHEM & 1.90 & 2.4 & 0.0045 & 0.00 & -2 & -1.0 \\
GISS-modelE & & & & -0.08 & & \\
GMI & 0.21 & 7.1 & 0.0015 & -0.06 & -291 & -40.9 \\
GOCART & & & & -0.02 & & \\
HadGEM2 & 0.48 & 8.0 & 0.0038 & -0.07 & -143 & -17.8 \\
IMPACT-Umich & 0.88 & 6.4 & 0.0056 & 0.07 & 84 & 13.1 \\
INCA & 1.76 & 8.4 & 0.0147 & -0.03 & -16 & -1.9 \\
MPIHAM & 0.07 & 22.6 & 0.0015 & 0.02 & 294 & 13.0 \\
NCAR-CAM3.5 & 0.21 & & & 0.02 & 95 & \\
OsloCTM2 & 0.47 & 6.0 & 0.0028 & 0.02 & 38 & 6.4 \\
SPRINTARS & & & & 0.00 & 0 & 0.0 \\
\hline Mean & 0.94 & 7.7 & 0.0054 & -0.00 & 7 & -2.1 \\
Median & 0.48 & 7.0 & 0.0038 & -0.00 & 24 & 4.5 \\
Stddev & 0.95 & 5.6 & 0.0054 & 0.05 & 158 & 18.4 \\
\hline
\end{tabular}

components. IMPACT-Umich and CAM5.1 have a clearer maximum over latitudes where industrialization is strong, whereas ECHAM5-HAM and OsloCTM2 have the maximum in the RF shifted slightly towards the Equator. The zonal pattern of the NRF is rather similar for the models, but the magnitude differs substantially, and one major cause here is assumptions regarding the optical properties and in particular the degree of absorption at short wavelength similar to primary OA discussed above. OsloCTM2 has the strongest NRF and uses pure scattering SOA. CAM5.1 has some positive NRF at very low SOA abundances and this model includes weak absorption of SOA at short wavelengths.

\subsection{RF nitrate}

Eight models have simulated RF of nitrate aerosols, explicitly. The resulting range of nitrate burdens has a larger span among the aerosol components than for sulphate and primary $\mathrm{BC}$ and $\mathrm{OA}$, ranging from 0.14 to $0.90 \mathrm{mg} \mathrm{m}^{-2}$ (see Table 8 and Fig. 12). The mean RF is $-0.08 \mathrm{Wm}^{-2}$ but, like the burden, the RF also varies widely among the AeroCom Phase II models with a range from -0.12 to $-0.02 \mathrm{Wm}^{-2}$. The pattern of the zonal mean burden of nitrate resembles the sulphate pattern. There is a tendency for models with weak sulphate burden to have a strong nitrate burden and vice versa and to some extent this can be expected since ammonium nitrate can only be formed if there is an excess of ammonia and thus it competes with sulphate (Adams et al., 2001). However, there are some exceptions to this relationship with some models having both low burden for sulphate and nitrate. The hygroscopic growth for nitrate is generally stronger than for sulphate (Fitzgerald, 1975) so one might expect stronger or at least similar MEC for nitrate compared to sulphate, but this is not the case for GMI and NCAR-CAM3.5. However, regional variation in the aerosols and thus water uptake may influence the results. The NRF with respect to burden and with respect to AOD are rather similar for nitrate and sulphate.

The mean RF of the DAE of nitrate is substantial and with its potentially larger role in the future it is important to investigate the model differences and compare with observations. We encourage studies comparing nitrate surface concentrations and in the atmosphere from aircraft measurements, which over Europe indicate a large role of nitrate (Crosier et al., 2007; Putaud et al., 2010), as well as over ocean where observations show small fractions fine mode nitrate (Quinn and Bates, 2005).

\subsection{RF BB}

The RF for simulated BB aerosol varies between positive and negative RF, highly dependent on SSA and likely also the altitude of the BB aerosols. The mean RF from the models is close to zero. The BB RF is weak in magnitude, but it is important to note that the RF of $\mathrm{BB}$ consists of a positive RF from $\mathrm{BC}$ and a negative RF from OA of much larger magnitude than for the total RF from BB aerosols. The MECs for $\mathrm{BB}$ aerosols given in Table 9 are in the upper range of what is measured during aerosol campaigns in Africa (Haywood et al., 2003; Johnson et al., 2008). In Schulz et al. (2006) the burden of primary carbonaceous was given separately for BC and OA, but not differentiated by sources. Since RF of OAFF and BCFF are at least not weaker and the total primary carbonaceous burden is lower than in Schulz et al. (2006) this 

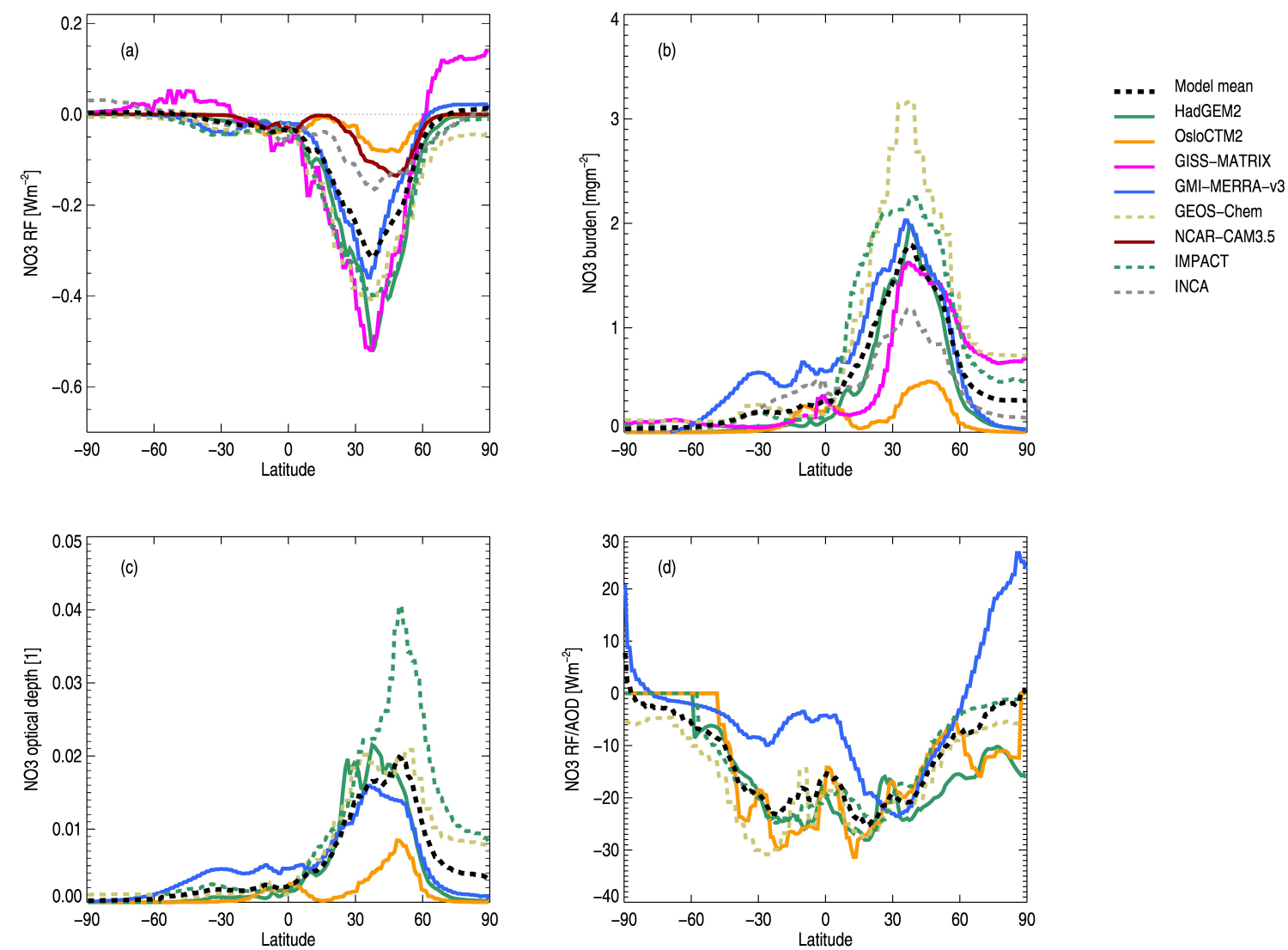

Fig. 12. Zonal mean $\mathrm{NO}_{3} \mathrm{RF}$ (a), burden (b), $\mathrm{AOD}$ at $550 \mathrm{~nm}$ (c), $\mathrm{NRF}(\mathrm{A})$ (d).

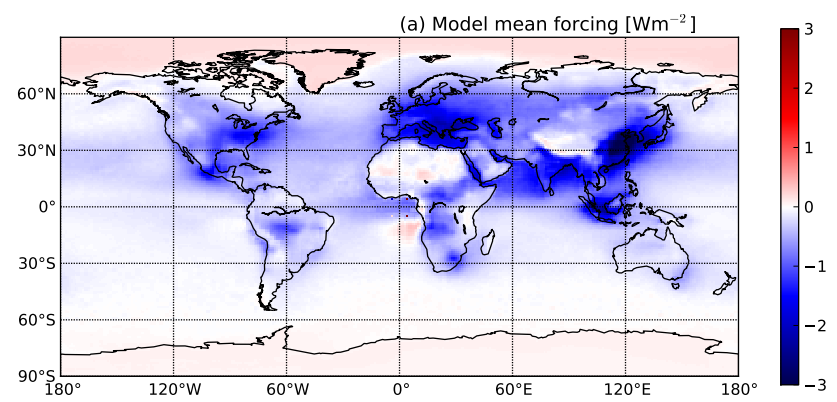

Fig. 13. Model mean RF (left) and standard deviation (right).

indicates lower BB burden in Phase II compared to Phase I. The model range in burden of $\mathrm{BB}$ is large as illustrated by the large difference between the mean and the median values. Zonal mean RF, burden, AOD and NRF with respect to AOD is shown for BB aerosols in Fig. S1.

\section{Discussion}

The geographical distributions of the RF of the total DAE and its uncertainty (given as one standard deviation) are shown in Fig. 13. As shown in earlier studies the RF of the DAE is strongly negative in industrialized regions of Asia, Europe

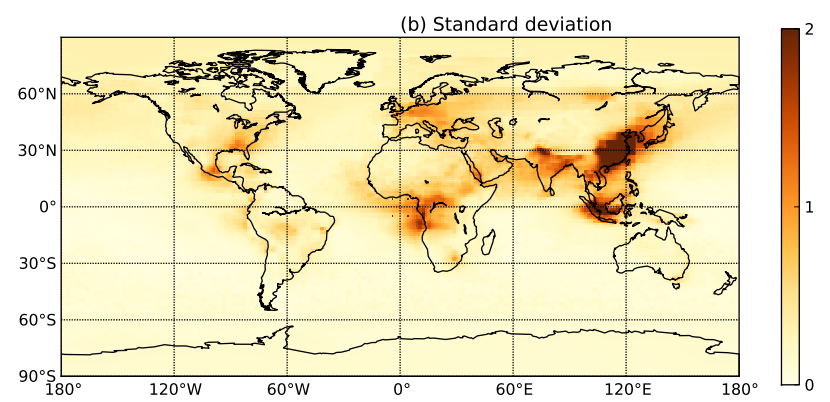

and Northern America and reaches positive RF at high latitudes and in other regions with high albedo (either high surface albedo or high cloud cover).

The model mean RF and standard deviation of DAE for sulphate, BC, and $\mathrm{OA}$ are shown in Fig. S2. Maximum strength in RF for sulphate, $\mathrm{BC}$, and $\mathrm{OA}$ is in Southeast Asia. For sulphate a quite strong RF is also simulated in Europe and Eastern US. Over regions with high surface albedo such as Sahara and Arctic the RF for sulphate and OA are quite weak, but RF from $B C$ is relatively strong. The standard deviations are highest in the regions of high RF. 

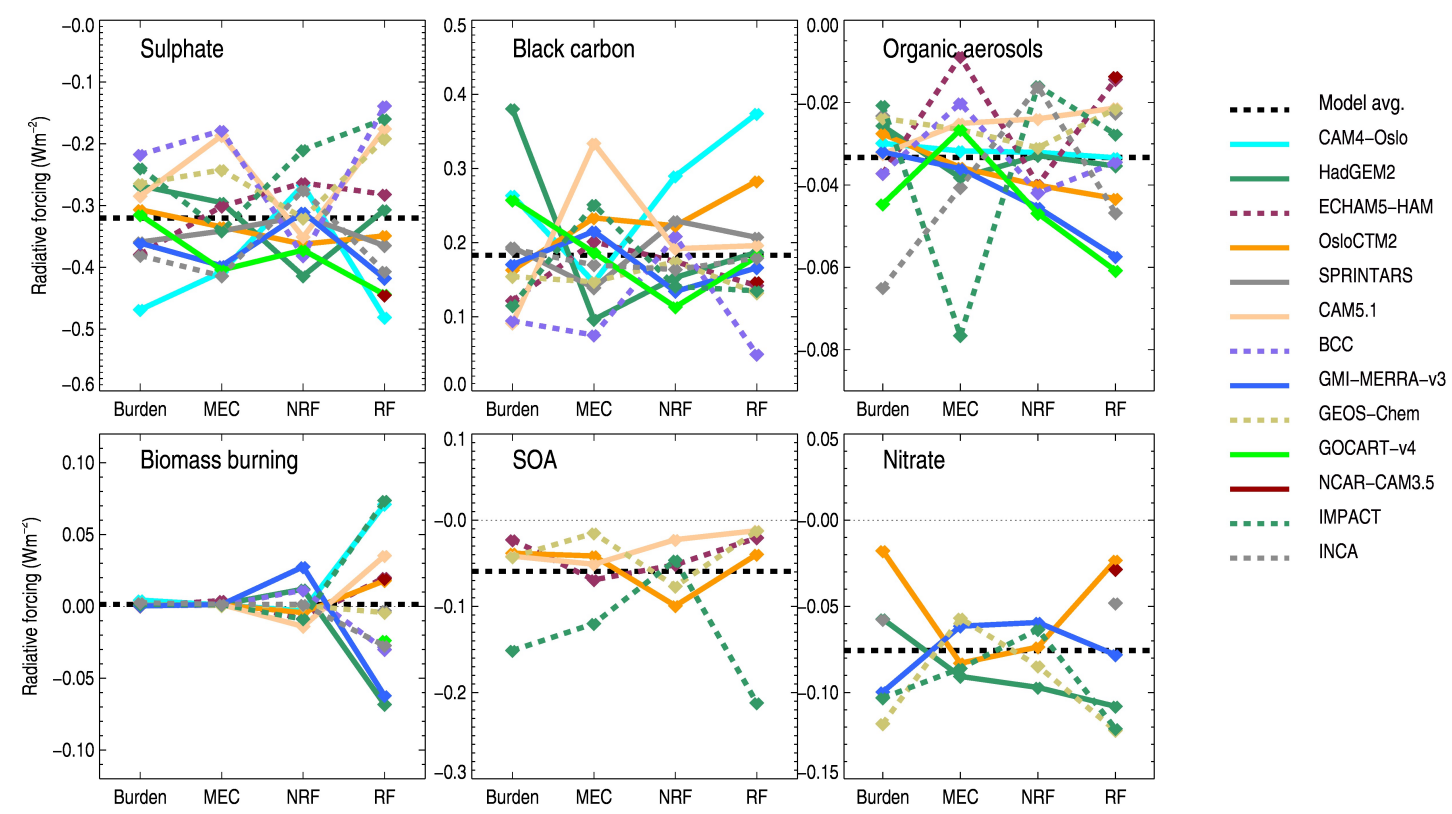

INCA

Fig. 14. Aerosol forcing partial sensitivities for the AeroCom models. The partial sensitivities are calculated as $P_{x, n}=x_{n} /<\times>*<\mathrm{RF}>$, where $n$ is model, $x$ is either burden, MEC, NRF (with respect to AOD) or RF, $<>$ denote mean values. Black dotted line is the mean of the AeroCom models. (Some of the results from the GISS-models are removed due to unresolved issues). Results shown for sulphate, black carbon, organic carbon, biomass burning, SOA, and nitrate as given in the figure.

The geographical distribution of RF by nitrate and SOA (Fig. S3) show similar pattern as for the other aerosol components (Fig. S2). For BB aerosols the geographical pattern of RF is very different from the other aerosol components. In some areas (southeast U. S.) this has been caused by reduction in $\mathrm{BB}$ emissions, but in other regions differing signs may be caused by the underlying albedo such as southern Africa (Chand et al., 2009; Keil and Haywood, 2003), where low albedo over land causes negative RF and large coverage of low lying clouds with BB aerosols above cause positive RF over ocean to the west of the coast. The high surface albedo at high latitudes is the major cause of the positive $\mathrm{RF}$ at high latitudes.

Schulz et al. (2006) introduced a way to investigate the contribution to the uncertainty from various key components in estimates of the RF of the direct aerosol effect. The same approach is shown in Fig. 14 for burden, MEC, NRF (with respect to AOD) and RF. The figure shows for each of burden, MEC, NRF and RF the contribution for the individual models to the diversity in the RF. For example one model may have a burden that contributes to a strong RF, but a MEC of opposite contribution. For sulphate the uncertainties in RF are slightly stronger than for the burden, MEC, NRF. However, the range for burden, MEC, NRF seems quite similar. CAM5, IMPACT, and BCC have the weakest RF. Weak MEC is shown to be a main reason for this for CAM5 and BCC, whereas for IMPACT burden and NRF are the main factors. CAM4-Oslo has the strongest sulphate RF. Here the burden is the main reason.
Whereas Schulz et al. (2006) found that diversity in NRF clearly dominated the diversity in RF of BC, Fig. 14 shows that diversities in burden and MEC are at least equally important in this study. Illustrative of how differences in burden, MEC, and NRF may compensate each other, the HadGEM2 model has the highest $\mathrm{BC}$ burden, but a RF of $\mathrm{BC}$ close to the mean, which can be seen to be caused by a rather low MEC. For OA the dominant cause for the spread in RF is differences in MEC, overwhelming the importance of differences in burden and NRF. ECHAM5-HAM has the weakest MEC of $1.6 \mathrm{~m}^{2} \mathrm{~g}^{-1}$ and IMPACT the strongest of $14.1 \mathrm{~m}^{2} \mathrm{~g}^{-1}$. The weak MEC for ECHAM5-HAM explains why it shows the weakest RF among the global aerosol models, since its burden and NRF are close to mean values.

The reasons for the differences in burden, MEC and NRF are numerous. For differences in NRF Randles et al. (2012) show that the radiative transfer scheme itself contributes to the diversity and Stier et al. (2012) further explores that host model differences such as surface albedo and clouds cause a substantial part of the diversity for the RF of the DAE. The differences in the aerosols vertical profile (Koffi et al., 2012; Schwarz et al., 2010) contribute to differences in NRF, especially for BC. Samset et al. (2012) show that $20-50 \%$ of the diversity in $\mathrm{RF}$ of $\mathrm{BC}$ is caused by the differences in the $\mathrm{BC}$ vertical profile. Further studies within AeroCom will explore other causes of the diversity in the results. Since most of the models in this study apply similar data sets for anthropogenic emissions of aerosols and their precursors, the uncertainties in this study do not include the full uncertainty 

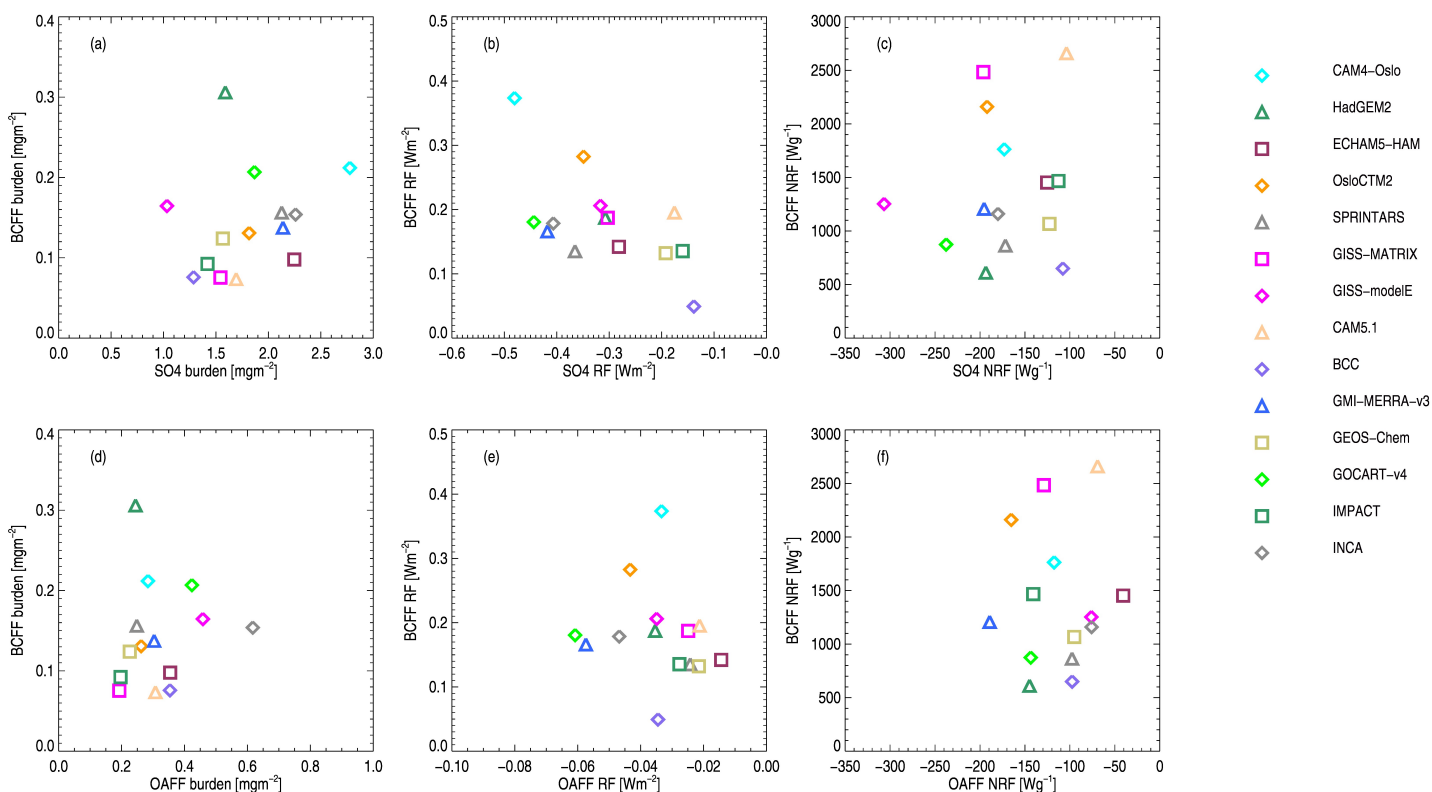

Fig. 15. Correlations between burdens (a and d), RF (b and e) and normalized forcing (c and $\mathbf{f}$ ), for $\mathrm{SO}_{4}$ vs $\mathrm{BCFF}(\mathbf{a}, \mathbf{b}$, and $\mathbf{c})$ and OCFF vs $\operatorname{BCFF}(\mathbf{d}, \mathbf{e}, \mathbf{f})$.

in the RF of the DAE. The difference in the background aerosol concentration (pre-industrial) between the models is of small importance for the RF of the DAE since RF is relatively linearly depending on the anthropogenically perturbed concentrations at current levels of the aerosol species.

Global aerosol models with strong RF for sulphate have a tendency to also have strong $\mathrm{RF}$ for $\mathrm{BC}$ and similar for $\mathrm{OA}$ in relation to BC. The RF sulphate and RF BC have an anticorrelation of 0.62 . Figure 15 shows the relationship between burden, RF and NRF for sulphate, BC and OA. Aerosol burden is dependent on dry and wet deposition and the transport schemes in the models, and the simulated burdens of various aerosol compounds are therefore correlated. Similarly, there is a tendency also for relationship between the NRF (with respect to burden) for various aerosol compounds. The total DAE which is the combined effect of all aerosol components with both positive $\mathrm{RF}$ (BC, and in some cases $\mathrm{OA}$ ) and negative RF (rest of components) thus also consists of RF contributions that are correlated. Altogether, this leads to smaller range in the total DAE than combining the range through error propagation rules for the individual aerosol components. This is illustrated in Fig. 16, which shows the PDFs for the individual aerosol components and their sum, and the modelled total RF. A narrower PDF for the model total DAE than aerosol component sum is evident. Further, Figure 16 illustrates the smaller model diversity when the aerosol missing component modification is performed compared to the total DAE directly from the various models.

The emission data used in most of the simulations (Lamarque et al., 2010) is generated for the period 1850 to 2000 . Anthropogenic emissions of aerosols and their precursors

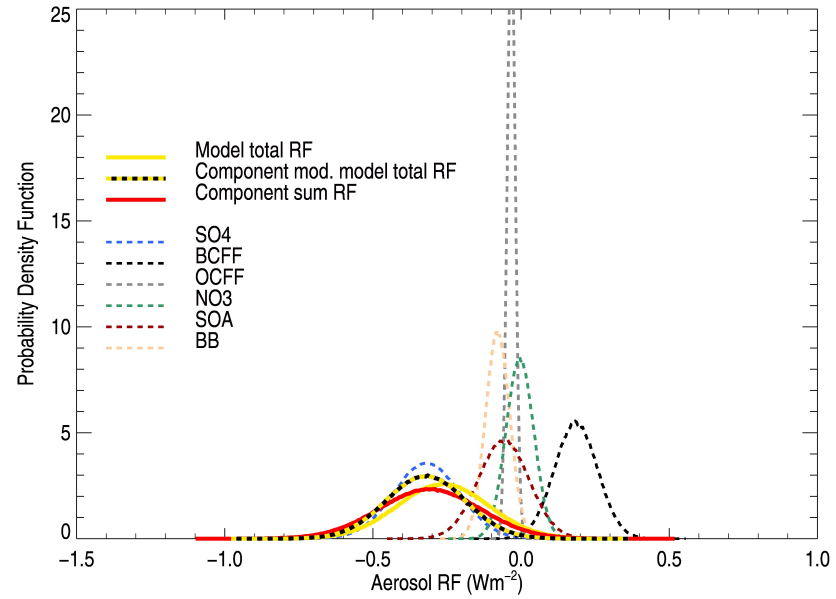

Fig. 16. Normalized PDFs of each aerosol component RF (dashed lines) based on the model spread shown above. The red line shows the mean of the modeled total aerosol RF, while the black line shows the spread when correcting for missing components as explained in the text.

had started in 1850 and emission changes have occurred after 2000. Skeie et al. (2011) performed RF simulations for OsloCTM2 for the different aerosol species for several time intervals for the period 1750 to 2000 based on Lamarque et al. (2010), as well as for 2010 based on the RCP4.5 scenario. GISS model simulations in Shindell et al. (2012) were also performed under the RCP4.5 scenario for years 2000 and 2010. Figure 17 shows a scaling of the AeroCom RF simulation for 1850-2000 to the extended time period 1750-2010. 


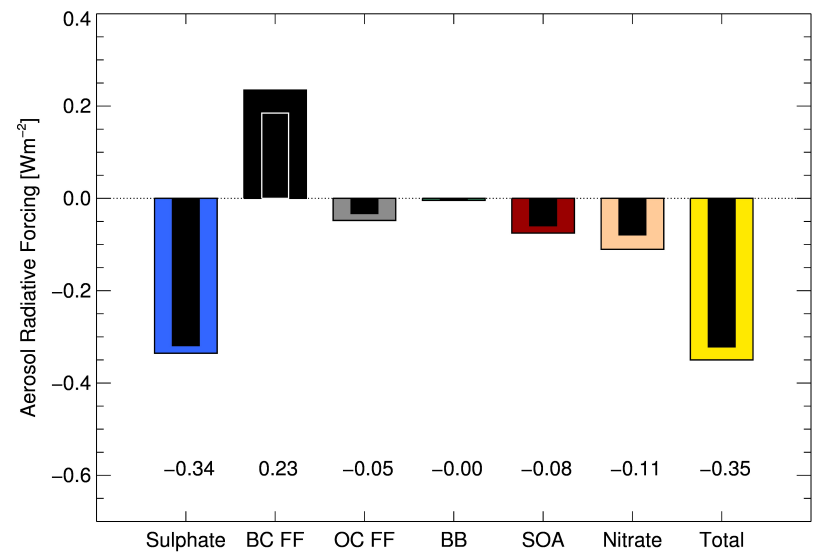

Fig. 17. Model mean RF per component (internal bars), modified from the study timeperiod of 1850-2000 to 1750-2010, based on numbers from Skeie et al. (2011). Details to be given in text.

To achieve this, we first calculate the aerosol component specific ratios of OsloCTM2 RF between 2010 and 1750 (Skeie et al., 2011) to RF between 2000 and 1850 (present work). Similar ratios are extracted using the GISS values from 2000 to 2010. The ratios from these two models are combined, and applied to each of the aerosol components individually. To scale the total RF, we then take the multi-model mean from the present work and add the sum of the component scalings. BB is excluded from this analysis, due to large uncertainties in BB activity between 1750 and 1850 as well as the inhomogeneous RF (see Fig. S3). The strengthening in the RF for $1750-2010$ relative to $1850-2000$ is particularly strong for $\mathrm{OA}$ from $\mathrm{FF}$ and $\mathrm{BF}$ and nitrate $(40-45 \%)$, quite important for BC from FF and BF and SOA (25-30\%), but rather small for sulphate $(5 \%)$. For OA from FF and BF, nitrate and SOA the largest strengthening occurs for the period 1750-1850 in comparison to the 2000-2010 period. For BC and sulphate the strengthening is rather similar in the 1750 1850 and 2000-2010 periods. The increase in BC emission from 2000 to 2010 is of similar magnitude in other emission data sets as we have applied in for the scaling (Granier et al., 2011). In Skeie et al. (2011) the increase in RF from $\mathrm{BC}$ (from FF and BF emissions) for the time period 2000 to 2010 was slightly larger than the associated increase in emissions due to also changes in the spatial pattern of the emissions. The increase in the RF of the primary carbonaceous aerosols from 2000 to 2010 were very similar in OsloCTM2 and GISS, but somewhat weaker for the secondary components in the GISS model compared to OsloCTM2. This indicates that uncertainties in the scaling are largest for nitrate and SOA which had a quite large change from 1750 to 1850. Taking into account the changes between 1750-1850 and 2000-2010 for the aerosol components changes the total DAE from $-0.32 \mathrm{Wm}^{-2}$ (modified for missing aerosol components) for $1850-2000$ to $-0.35 \mathrm{Wm}^{-2}$ for the $1750-2010$ period.

\section{Conclusions}

We have documented the RF of the DAE for anthropogenic aerosol emissions from 16 global aerosol models, combined and for sulphate, BC, OA, BB, nitrate and SOA separately. This AeroCom Phase II DAE experiment shows many similarities with the Phase I (Schulz et al., 2006), even though more models are included here and model development has taken place over the intervening years. We summarize here the most important findings:

- The total RF of DAE is more strongly negative in the current simulations than in AeroCom Phase I. The main reason for this is addition of new species such as nitrate and SOA.

- Sulphate and BC from FF and BF emissions are the two aerosol components with strongest absolute RF. The RF of the DAE of sulphate is very similar in the simulations presented here and in Schulz et al. (2006). On the other hand $\mathrm{BC}$ RF from FF and BF emissions is almost twice as strong compared to in Schulz et al. (2006).

- The global aerosol models have undergone substantial development over the last $7-8 \mathrm{yr}$, and while there are some changes relative to AeroCom Phase I (Schulz et al., 2006), the present analysis shows that the main estimates across AeroCom Phase I and II are quite robust. This is both with respect to mean estimates and uncertainty range, with the main exception that the $\mathrm{BC} \mathrm{RF}$ from FF and BF is substantial stronger in Phase II compared to Phase 1.

- The mean from the 16 models of the RF of the total DAE is $-0.27 \mathrm{Wm}^{-2}$. Several of the AeroCom models have not included either nitrate aerosols or SOA or both. Modifying these models with information from AeroCom models altogether results in a mean RF of $-0.32 \mathrm{Wm}^{-2}$. The model simulations are to a large extent performed for the period 1850-2000 and using available information to scale to $1750-2010$ results in a mean RF of the total DAE of $-0.35 \mathrm{Wm}^{-2}$.

- The AeroCom Phase II simulated 1850-2000 (four models use slightly different time period) mean RF of the DAE for sulphate is $-0.32 \mathrm{Wm}^{-2}$, BC from FF and $\mathrm{BF}$ emissions is $+0.18 \mathrm{Wm}^{-2}$, $\mathrm{OA}$ from $\mathrm{FF}$ and $\mathrm{BF}$ emissions is $-0.03 \mathrm{Wm}^{-2}$, $\mathrm{BB}$ is $-0.00 \mathrm{Wm}^{-2}$, nitrate is $-0.08 \mathrm{Wm}^{-2}$ and SOA is $-0.06 \mathrm{Wm}^{-2}$. When these numbers were scaled to 1750-2010 numbers the $\mathrm{RF}$ for sulphate is $-0.34 \mathrm{Wm}^{-2}, \mathrm{BC}$ from $\mathrm{FF}$ and $\mathrm{BF}$ emissions is $+0.23 \mathrm{Wm}^{-2}$, $\mathrm{OA}$ from $\mathrm{FF}$ and $\mathrm{BF}$ emissions is $-0.05 \mathrm{Wm}^{-2}, \mathrm{BB}$ is $-0.00 \mathrm{Wm}^{-2}$ (no change included), nitrate is $-0.11 \mathrm{Wm}^{-2}$ and SOA is $-0.08 \mathrm{Wm}^{-2}$.

- The differences between models are large for the DAE of the aerosol components, as illustrated by the relative 
standard deviation of more than $40 \%$ for RF of BC and a range from 0.05 to $0.37 \mathrm{Wm}^{-2}$. A further understanding of the causes of the uncertainties is attempted by decomposing the results into diversities due to burden, MEC, and NRF. In general these three factors contribute equally to the uncertainty in the DAE.

- We find a correlation in the magnitude of RF of BC (positive) and RF of sulphate or OA (negative) among the models, due to transport, deposition, and optical properties being treated similarly in each of the models. We therefore find a smaller uncertainty in the total DAE than the sum of the DAE by aerosol components.

\section{Supplementary material related to this article is available online at: http://www.atmos-chem-phys.net/13/ 1853/2013/acp-13-1853-2013-supplement.pdf.}

Acknowledgements. S. Ghan, X. Liu, R. Easter, P. Rasch and J.-H. Yoon were funded by the US Department of Energy, Office of Science, Scientific Discovery through Advanced Computing (SciDAC) Program and by the Office of Science Earth System Modeling Program. Computing resources were provided by the Climate Simulation Laboratory at NCAR's Computational and Information Systems Laboratory (CISL), sponsored by the National Science Foundation and other agencies. The Pacific Northwest National Laboratory is operated for DOE by Battelle Memorial Institute under contract DE-AC06- 76RLO 1830. Simulations of the ECHAM5-HAM, INCA, CAM4-Oslo and HadGEM2 models have been supported with funds from the FP6 project EUCAARI (Contract 34684). A. Kirkevåg, T. Iversen and Ø. Seland (CAM4Oslo) were supported by the Research Council of Norway through the EarthClim (207711/E10) and NOTUR/NorStore projects, by the Norwegian Space Centre through PM-VRAE, and through the EU projects PEGASOS and ACCESS. H. Zhang and Z. Wang were funded by National Basic Research Program of China (2011CB403405). G. Luo, X. Ma and F. Yu were funded by the US NSF (AGS-0942106) and NASA (NNX11AQ72G). K. Tsigaridis and S. Bauer were supported by NASA-MAP (NASA award NNX09AK32G). Resources supporting this work were provided by the NASA High-End Computing (HEC) Program through the NASA Center for Climate Simulation (NCCS) at Goddard Space Flight Center. N. Bellouin was supported by the Joint DECC/Defra Met Office Hadley Centre Climate Programme (GA01101). G. Myhre and B. Samset were funded by the Research Council of Norway through the EarthClim and SLAC projects and the EU-project ECLIPSE.

Edited by: E. Highwood

\section{References}

Aan de Brugh, J., Schaap, M., Vignati, E., Dentener, F., Kahnert, M., Sofiev, M., Huijnen, V., and Krol, M. C.: The European aerosol budget in 2006, Atmos. Chem. Phys., 11, 1117-1139, doi:10.5194/acp-11-111-2011, 2011.

Adams, P. J., Seinfeld, J. H., Koch, D., Mickley, L., and Jacob, D.: General circulation model assessment of direct radiative forcing by the sulfate-nitrate-ammonium-water inorganic aerosol system, J. Geophys. Res.-Atmos., 106, 1097-1111, 2001.

Balkanski, Y.: L'influence des aérosols sur le climat, Thèse d'Habilitation à Diriger des Recherches. Université Versailles Saint Quentin, France, 2011.

Balkanski, Y., Schulz, M., Moulin, C., and Ginoux, P., The formulation of dust emissions on global scale: formulation and validation using satellite retrievals. In: Emissions of Atmospheric Trace Compounds. C. Granier, P. Artaxo and C. Reeves (Editors), Kluwer Academic Publishers, Dordrecht, The Netherlands, 239-267, 2004.

Bauer, S. E., Koch, D., Unger, N., Metzger, S. M., Shindell, D. T., and Streets, D. G.: Nitrate aerosols today and in 2030: a global simulation including aerosols and tropospheric ozone, Atmos. Chem. Phys., 7, 5043-5059, doi:10.5194/acp-7-5043-2007, 2007.

Bauer, S. E., Wright, D. L., Koch, D., Lewis, E. R., McGraw, R., Chang, L. S., Schwartz, S. E., and Ruedy, R.: MATRIX (Multiconfiguration Aerosol TRacker of mIXing state): an aerosol microphysical module for global atmospheric models, Atmos. Chem. Phys., 8, 6003-6035, doi:10.5194/acp-8-60032008, 2008.

Bauer, S. E., Menon, S., Koch, D., Bond, T. C. and Tsigaridis, K.: A global modeling study on carbonaceous aerosol microphysical characteristics and radiative effects, Atmos. Chem. Phys., 10, 7439-7456, doi:10.5194/acp-10-7439-2010, 2010.

Bellouin, N., Boucher, O., Haywood, J., and Reddy, M. S.: Global estimate of aerosol direct radiative forcing from satellite measurements, Nature, 438, 1138-1141, 2005.

Bellouin, N., Jones, A., Haywood, J., and Christopher, S. A.: Updated estimate of aerosol direct radiative forcing from satellite observations and comparison against the Hadley Centre climate model, J. Geophys. Res.-Atmos., 113, D10205, doi:10.1029/2007jd009385, 2008.

Bellouin, N., Rae, J., Jones, A., Johnson, C., Haywood, J., and Boucher, O.: Aerosol forcing in the Climate Model Intercomparison Project (CMIP5) simulations by HadGEM2-ES and the role of ammonium nitrate, J. Geophys. Res.-Atmos., 116, D20206, doi:10.1029/2011jd016074, 2011.

Bian, H., Chin, M., Rodriguez, J. M., Yu, H., Penner, J. E., and Strahan, S.: Sensitivity of aerosol optical thickness and aerosol direct radiative effect to relative humidity, Atmos. Chem. Phys., 9, 2375-2386, doi:10.5194/acp-9-2375-2009, 2009.

Bond, T. C. and Bergstrom, R. W.: Light absorption by carbonaceous particles: An investigative review, Aerosol Sci. Technol., 40, 27-67, 2006.

Bond, T. C., Habib, G., and Bergstrom, R. W.: Limitations in the enhancement of visible light absorption due to mixing state, J. Geophys. Res.-Atmos., 111, D20211, doi:10.1029/2006JD007315, 2006.

Cappa, C. D., Onasch, T. B., Massoli, P., Worsnop, D. R., Bates, T. S., Cross, E. S., Davidovits, P., Hakala, J., Hayden, K. L., Job- 
son, B. T., Kolesar, K. R., Lack, D. A., Lerner, B. M., Li, S. M., Mellon, D., Nuaaman, I., Olfert, J. S., Petaja, T., Quinn, P. K., Song, C., Subramanian, R., Williams, E. J., and Zaveri, R. A.: Radiative Absorption Enhancements Due to the Mixing State of Atmospheric Black Carbon, Science, 337, 1078-1081, 2012.

Chand, D., Wood, R., Anderson, T. L., Satheesh, S. K., and Charlson, R. J.: Satellite-derived direct radiative effect of aerosols dependent on cloud cover, Nature Geosci., 2, 181-184, 2009.

Charlson, R. J., Langner, J., Rodhe, H., Leovy, C. B., and Warren, S. G.: Perturbation of the Northern-Hemisphere Radiative Balance by Backscattering from Anthropogenic Sulfate Aerosols, Tellus A - Dynam. Meteorol. Oceanogr., 43, 152-163, 1991.

Chin, M., Ginoux, P., Kinne, S., Torres, O., Holben, B. N., Duncan, B. N., Martin, R. V., Logan, J. A., Higurashi, A. and Nakajima, T.: Tropospheric aerosol optical thickness from the GOCART model and comparisons with satellite and Sun photometer measurements, J. Atmos. Sci., 59, 461-483, 2002.

Chin, M., Rood, R. B., Lin, S. J., Muller, J. F., and Thompson, A. M.: Atmospheric sulfur cycle simulated in the global model GOCART: Model description and global properties, J. Geophys. Res.-Atmos., 105, 24671-24687, 2000.

Chung, C. E., Ramanathan, V., Kim, D., and Podgorny, I. A.: Global anthropogenic aerosol direct forcing derived from satellite and ground-based observations, J. Geophys. Res.-Atmos., 110, D24207, doi:10.1029/2005JD006356, 2005.

Chung, C. E., Lee, K., and Muller, D.: Effect of internal mixture on black carbon radiative forcing, Tellus B - Chem. Phys. Meteorol., 64, 1-13, 2012.

Crosier, J., Allan, J. D., Coe, H., Bower, K. N., Formenti, P., and Williams, P. I.: Chemical composition of summertime aerosol in the Po Valley (Italy), northern Adriatic and Black Sea, Q. J. Roy. Meteorol. Soc., 133, 61-75, 2007.

Feng, Y. and Penner, J. E.: Global modeling of nitrate and ammonium: Interaction of aerosols and tropospheric chemistry, J. Geophys. Res.-Atmos., 112, D01304, doi:10.1029/2005JD006404, 2007.

Fitzgerald, J. W.: Approximation Formulas For Equilibrium Size Of An Aerosol Particle As A Function Of Its Dry Size And Composition And Ambient Relative Humidity, J. Appl. Meteorol., 14, 1044-1049, 1975.

Forster, P., Ramaswamy, V., Artaxo, P., Berntsen, T., Betts, R., Fahey, D. W., Haywood, J., Lean, J., Lowe, D. C., Myhre, G., Nganga, J., Prinn, R., Raga, G., Schulz, M., and Van Dorland, R., Changes in Atmospheric Constituents and in Radiative Forcing. In: Climate Change 2007: The Physical Science Basis. Contribution of Working Group I to the Fourth Assessment Report of the Intergovernmental Panel on Climate Change, Cambridge University Press, Cambridge, United Kingdom and New York, NY, USA, 2007.

Fuller, K. A., Malm, W. C., and Kreidenweis, S. M.: Effects of mixing on extinction by carbonaceous particles, J. Geophys. Res.Atmos., 104, 15941-15954, 1999.

Ghan, S. J., Liu, X., Easter, R. C., Zaveri, R., Rasch, P. J., Yoon, J.-H. and Eaton, B.: Toward a minimal representation of aerosols in climate models: Comparative decomposition of aerosol direct, semi-direct and indirect radiative forcing, J. Climate, 25, 64616476, doi:10.1175/JCLI-D-11-00650.1, 2012.

Ginoux, P., Chin, M., Tegen, I., Prospero, J. M., Holben, B., Dubovik, O., and Lin, S. J.: Sources and distributions of dust aerosols simulated with the GOCART model, J. Geophys. Res.Atmos., 106, 20255-20273, 2001.

Granier, C., Bessagnet, B., Bond, T., D’Angiola, A., van der Gon, H. D., Frost, G. J., Heil, A., Kaiser, J. W., Kinne, S., Klimont, Z., Kloster, S., Lamarque, J. F., Liousse, C., Masui, T., Meleux, F., Mieville, A., Ohara, T., Raut, J. C., Riahi, K., Schultz, M. G., Smith, S. J., Thompson, A., van Aardenne, J., van der Werf, G. R., and van Vuuren, D. P.: Evolution of anthropogenic and biomass burning emissions of air pollutants at global and regional scales during the 1980-2010 period, Clim. Change, 109, 163-190, 2011.

Haywood, J. M. and Shine, K. P.: The effect of anthropogenic sulfate and soot aerosol on the clear-sky planetary radiation budget, Geophys. Res. Lett., 22, 603-606, 1995.

Haywood, J. M., Osborne, S. R., Francis, P. N., Keil, A., Formenti, P., Andreae, M. O., and Kaye, P. H.: The mean physical and optical properties of regional haze dominated by biomass burning aerosol measured from the C-130 aircraft during SAFARI 2000, J. Geophys. Res.-Atmos., 108, 8473, doi:10.1029/2002/JD002226, 2003.

Heald, C. L., Coe, H., Jimenez, J. L., Weber, R. J., Bahreini, R., Middlebrook, A. M., Russell, L. M., Jolleys, M., Fu, T. M., Allan, J. D., Bower, K. N., Capes, G., Crosier, J., Morgan, W. T., Robinson, N. H., Williams, P. I., Cubison, M. J., DeCarlo, P. F., and Dunlea, E. J.: Exploring the vertical profile of atmospheric organic aerosol: comparing 17 aircraft field campaigns with a global model, Atmos. Chem. Phys., 11, 12673-12696, doi:10.5194/acp-11-12673-2011, 2011.

Holben, B. N., Eck, T. F., Slutsker, I., Tanre, D., Buis, J. P., Setzer, A., Vermote, E., Reagan, J. A., Kaufman, Y. J., Nakajima, T., Lavenu, F., Jankowiak, I., and Smirnov, A.: AERONET - A federated instrument network and data archive for aerosol characterization, Remote Sens. Environ., 66, 1-16, 1998.

Hoyle, C. R., Myhre, G., Berntsen, T. K., and Isaksen, I. S. A.: Anthropogenic influence on SOA and the resulting radiative forcing, Atmos. Chem. Phys., 9, 2715-2728, doi:10.5194/acp-9-27152009, 2009.

Hoyle, C. R., Boy, M., Donahue, N. M., Fry, J. L., Glasius, M., Guenther, A., Hallar, A. G., Hartz, K. H., Petters, M. D., Petaja, T., Rosenoern, T., and Sullivan, A. P.: A review of the anthropogenic influence on biogenic secondary organic aerosol, Atmos. Chem. Phys., 11, 321-343, doi:10.5194/acp-11-321-2011, 2011.

Huneeus, N., Schulz, M., Balkanski, Y., Griesfeller, J., Prospero, J., Kinne, S., Bauer, S., Boucher, O., Chin, M., Dentener, F., Diehl, T., Easter, R., Fillmore, D., Ghan, S., Ginoux, P., Grini, A., Horowitz, L., Koch, D., Krol, M. C., Landing, W., Liu, X., Mahowald, N., Miller, R., Morcrette, J. J., Myhre, G., Penner, J., Perlwitz, J., Stier, P., Takemura, T., and Zender, C. S.: Global dust model intercomparison in AeroCom phase I, Atmos. Chem. Phys., 11, 7781-7816, doi:10.5194/acp-11-7781-2011, 2011.

Jacobson, M. Z.: Investigating cloud absorption effects: Global absorption properties of black carbon, tar balls, and soil dust in clouds and aerosols, J. Geophys. Res.-Atmos., 117, D06205, doi:10.1029/2011jd017218, 2012.

Johnson, B. T., Osborne, S. R., Haywood, J. M., and Harrison, M. A. $\mathrm{J}$.: Aircraft measurments of biomass burning aerosols over West Africa during DABEX, J. Geophys. Res.-Atmos., 113, D00C06, doi:10.1029/2007JD009451, 2008. 
Kanakidou, M., Seinfeld, J. H., Pandis, S. N., Barnes, I., Dentener, F. J., Facchini, M. C., Van Dingenen, R., Ervens, B., Nenes, A., Nielsen, C. J., Swietlicki, E., Putaud, J. P., Balkanski, Y., Fuzzi, S., Horth, J., Moortgat, G. K., Winterhalter, R., Myhre, C. E. L., Tsigaridis, K., Vignati, E., Stephanou, E. G., and Wilson, J.: Organic aerosol and global climate modelling: a review, Atmos. Chem. Phys., 5, 1053-1123, doi:10.5194/acp-5-1053-2005, 2005.

Keil, A. and Haywood, J. M.: Solar radiative forcing by biomass burning aerosol particles during SAFARI 2000: A case study based on measured aerosol and cloud properties, J. Geophys. Res.-Atmos., 108, 8467, doi:10.1029/2002JD002315, 2003.

Kirkevåg, A., Iversen, T., Seland, Ø., Hoose, C., Kristjansson, J. E., Struthers, H., Ekman, A. M. L., Ghan, S., Griesfeller, J., Nilsson, E. D. and Schulz, M.: Aerosol-climate interactions in the Norwegian Earth System Model - Nor-ESM, Geosci. Model Dev. Discuss, 5, 2599-2685, doi:10.5194/gmdd-5-2599-2012, 2012.

Koch, D., Schmidt, G. A., and Field, C. V.: Sulfur, sea salt, and radionuclide aerosols in GISS ModelE, J. Geophys. Res.-Atmos., 111, D06206, doi:10.1029/2004jd005550, 2006.

Koch, D., Bond, T. C., Streets, D., Unger, N., and van der Werf, G. R.: Global impacts of aerosols from particular source regions and sectors, J. Geophys. Res.-Atmos., 112, D02205, doi:10.1029/2005jd007024, 2007.

Koch, D., Schulz, M., Kinne, S., McNaughton, C., Spackman, J. R., Balkanski, Y., Bauer, S., Berntsen, T., Bond, T. C., Boucher, O., Chin, M., Clarke, A., De Luca, N., Dentener, F., Diehl, T., Dubovik, O., Easter, R., Fahey, D. W., Feichter, J., Fillmore, D., Freitag, S., Ghan, S., Ginoux, P., Gong, S., Horowitz, L., Iversen, T., Kirkevag, A., Klimont, Z., Kondo, Y., Krol, M., Liu, X., Miller, R., Montanaro, V., Moteki, N., Myhre, G., Penner, J. E., Perlwitz, J., Pitari, G., Reddy, S., Sahu, L., Sakamoto, H., Schuster, G., Schwarz, J. P., Seland, O., Stier, P., Takegawa, N., Takemura, T., Textor, C., van Aardenne, J. A., and Zhao, Y.: Evaluation of black carbon estimations in global aerosol models, Atmos. Chem. Phys., 9, 9001-9026, doi:10.5194/acp-9-9001-2009, 2009.

Koffi, B., Schulz, M., Breon, F. M., Griesfeller, J., Winker, D., Balkanski, Y., Bauer, S., Berntsen, T., Chin, M. A., Collins, W. D., Dentener, F., Diehl, T., Easter, R., Ghan, S., Ginoux, P., Gong, S. L., Horowitz, L. W., Iversen, T., Kirkevåg, A., Koch, D., Krol, M., Myhre, G., Stier, P., and Takemura, T.: Application of the CALIOP layer product to evaluate the vertical distribution of aerosols estimated by global models: AeroCom phase I results, J. Geophys. Res.-Atmos., 117, D10201, doi:10.1029/2011jd016858, 2012.

Lamarque, J., Bond, T., Eyring, V., Granier, C., Heil, A., Klimont, Z., Lee, D., Liousse, C., Mieville, A., Owen, B., Schultz, M., Shindell, D., Smith, S., Stehfest, E., Van Aardenne, J., Cooper, O., Kainuma, M., Mahowald, N., McConnell, J., Naik, V., Riahi, K., and van Vuuren, D.: Historical (1850-2000) gridded anthropogenic and biomass burning emissions of reactive gases and aerosols: methodology and application, Atmos. Chem. Phys., 10, 7017-7039, doi:10.5194/acp-10-7017-2010, 2010.

Lamarque, J. F., Emmons, L. K., Hess, P. G., Kinnison, D. E., Tilmes, S., Vitt, F., Heald, C. L., Holland, E. A., Lauritzen, P. H., Neu, J., Orlando, J. J., Rasch, P. J., and Tyndall, G. K.: CAM-chem: description and evaluation of interactive atmospheric chemistry in the Community Earth System Model,
Geosci. Model Dev., 5, 369-411, doi:10.5194/gmd-5-369-2012, Liao, H. and Seinfeld, J. H.: Effect of clouds on direct aerosol radiative forcing of climate, J. Geophys. Res.-Atmos., 103, 37813788, 1998.

Liao, H. and Seinfeld, J. H.: Global impacts of gas-phase chemistryaerosol interactions on direct radiative forcing by anthropogenic aerosols and ozone, J. Geophys. Res., 110, D18208, doi:10.1029/2005JD005907, 2005.

Lin, G., Penner, J. E., Sillman, S., Taraborrelli, D., and Lelieveld, J.: Global modeling of SOA formation from dicarbonyls, epoxides, organic nitrates and peroxides, Atmos. Chem. Phys., 12, 4743 4774, doi:10.5194/acp-12-4743-2012, 2012.

Liu, X., Easter, R. C., Ghan, S. J., Zaveri, R., Rasch, P., Lamarque, J.-F., Gettelman, A., Morrison, H., Vitt, F., Conley, A., Park, S., Neale, R., Hannay, C., Ekman, A., Hess, P., Mahowald, N., Collins, W., Iacono, M., Bretherton, C., Flanner, M., and Mitchell, D.: Toward a minimal representation of aerosols in climate models: Description and evaluation in the Community Atmosphere Model CAM5., Geosci. Model Dev., 5, 709-739, doi:10.5194/gmd-5-709-2012, 2012.

Ma, X., Yu, F., and Luo, G.: Aerosol direct radiative forcing based on GEOS-Chem-APM and uncertainties, Atmos. Chem. Phys., 12, 5563-5581, doi:10.5194/acp-12-5563-2012, 2012.

Metzger, S., Dentener, F., Krol, M., Jeuken, A., and Lelieveld, J.: Gas/aerosol partitioning - 2. Global modeling results, J. Geophys. Res.-Atmos., 107, 4313, doi:10.1029/2001JD001103, 2002.

Mian Chin, Diehl, T., Dubovik, O., Eck, T. F., Holben, B. N., Sinyuk, A., and Streets, D. G.: Light absorption by pollution, dust, and biomass burning aerosols: a global model study and evaluation with AERONET measurements, Ann. Geophys., 27, 3439-3464, doi:10.5194/angeo-27-3439-2009, 2009.

Myhre, G.: Consistency between satellite-derived and modeled estimates of the direct aerosol effect, Science, 325, 187-190, 2009.

Myhre, G., Bellouin, N., Berglen, T. F., Berntsen, T. K., Boucher, O., Grini, A., Isaksen, I. S. A., Johnsrud, M., Mishchenko, M. I., Stordal, F., and Tanre, D.: Comparison of the radiative properties and direct radiative effect of aerosols from a global aerosol model and remote sensing data over ocean, Tellus B - Chem. Phys. Meteorol., 59, 115-129, 2007.

Myhre, G., Berglen, T. F., Johnsrud, M., Hoyle, C. R., Berntsen, T. K., Christopher, S. A., Fahey, D. W., Isaksen, I. S. A., Jones, T. A., Kahn, R. A., Loeb, N., Quinn, P., Remer, L., Schwarz, J. P., and Yttri, K. E.: Modelled radiative forcing of the direct aerosol effect with multi-observation evaluation, Atmos. Chem. Phys., 9, 1365-1392, doi:10.5194/acp-9-1365-2009, 2009.

Putaud, J. P., Van Dingenen, R., Alastuey, A., Bauer, H., Birmili, W., Cyrys, J., Flentje, H., Fuzzi, S., Gehrig, R., Hansson, H. C., Harrison, R. M., Herrmann, H., Hitzenberger, R., Huglin, C., Jones, A. M., Kasper-Giebl, A., Kiss, G., Kousa, A., Kuhlbusch, T. A. J., Loschau, G., Maenhaut, W., Molnar, A., Moreno, T., Pekkanen, J., Perrino, C., Pitz, M., Puxbaum, H., Querol, X., Rodriguez, S., Salma, I., Schwarz, J., Smolik, J., Schneider, J., Spindler, G., ten Brink, H., Tursic, J., Viana, M., Wiedensohler, A. and Raes, F.: A European aerosol phenomenology-3: Physical and chemical characteristics of particulate matter from 60 rural, urban, and kerbside sites across Europe, Atmos. Environ., 44, 1308-1320, 2010 . 
Quaas, J., Boucher, O., Bellouin, N., and Kinne, S.: Satellite-based estimate of the direct and indirect aerosol climate forcing, J. Geophys. Res.-Atmos., 113, D05204, doi:10.1029/2007jd008962, 2008.

Quinn, P. K. and Bates, T. S.: Regional aerosol properties: Comparisons of boundary layer measurements from ACE 1, ACE 2, aerosols99, INDOEX, ACE asia, TARFOX, and NEAQS, J. Geophys. Res.-Atmos., 110, D14202, doi:10.1029/2004JD004755, 2005.

Ramanathan, V. and Carmichael, G.: Global and regional climate changes due to black carbon, Nature Geosci., 1, 221-227, 2008.

Randles, C. A., Kinne, S., Myhre, G., Schulz, M., Stier, P., Fischer, J., Doppler, L., Highwood, E., Ryder, C., Harris, B., Huttunen, J., Ma, Y., Pinker, R. T., Mayer, B., Neubauer, D., Hitzenberger, R., Oreopoulos, L., Lee, D., Pitari, G., Di Genova, G., Quaas, J., Rose, Fred G., Kato, S., Rumbold, S. T., Vardavas, I., Hatzianastassiou, N., Matsoukas, C., Yu, H., Zhang, F., Zhang, H., and $\mathrm{Lu}, \mathrm{P}$.: Intercomparison of shortwave radiative transfer schemes in global aerosol modeling: results from the AeroCom Radiative Transfer Experiment, Atmos. Chem. Phys. Discuss., 12, 3263132706, doi:10.5194/acpd-12-32631-2012, 2012.

Rasch, P. J., Feichter, J., Law, K., Mahowald, N., Penner, J., Benkovitz, C., Genthon, C., Giannakopoulos, C., Kasibhatla, P., Koch, D., Levy, H., Maki, T., Prather, M., Roberts, D. L., Roelofs, G. J., Stevenson, D., Stockwell, Z., Taguchi, S., Kritz, M., Chipperfield, M., Baldocchi, D., McMurry, P., Barrie, L., Balkansi, Y., Chatfield, R., Kjellstrom, E., Lawrence, M., Lee, H. N., Lelieveld, J., Noone, K. J., Seinfeld, J., Stenchikov, G., Schwartz, S., Walcek, C. and Williamson, D.: A comparison of scavenging and deposition processes in global models: results from the WCRP Cambridge Workshop of 1995, Tellus B - Chem. Phys. Meteorol., 52, 1025-1056, 2000.

Remer, L. A., Kleidman, R. G., Levy, R. C., Kaufman, Y. J., Tanre, D., Mattoo, S., Martins, J. V., Ichoku, C., Koren, I., Yu, H. B., and Holben, B. N.: Global aerosol climatology from the MODIS satellite sensors, J. Geophys. Res.-Atmos., 113, D14S07, doi:10.1029/2007jd009661, 2008.

Robinson, A. L., Donahue, N. M., Shrivastava, M. K., Weitkamp, E. A., Sage, A. M., Grieshop, A. P., Lane, T. E., Pierce, J. R., and Pandis, S. N.: Rethinking organic aerosols: Semivolatile emissions and photochemical aging, Science, 315, 1259-1262, 2007.

Samset, B. H. and Myhre, G.: Vertical dependence of black carbon, sulphate and biomass burning aerosol radiative forcing, Geophys. Res. Lett., 38, L24802, doi:10.1029/2011gl049697, 2011.

Samset, B. H., Myhre, G., Schulz, M., Balkanski, Y., Bauer, S., Berntsen, T. K., Bian, H., Bellouin, N., Diehl, T., Easter, R. C., Ghan, S. J., Iversen, T., Kinne, S., Kirkevåg, A., Lamarque, J.-F., Lin, G., Liu, X., Penner, J., Seland, Ø., Skeie, R. B., Stier, P., Takemura, T., Tsigaridis, K., and Zhang, K.: Black carbon vertical profiles strongly affect its radiative forcing uncertainty, Atmos. Chem. Phys. Discuss., 12, 28929-28953, doi:10.5194/acpd-12-28929-2012, 2012.

Schulz, M.: Constraining model estimates of the aerosol radiative forcing. Habilitation Thesis Thesis, Université Pierre et Marie Curie, Paris VI, 2007.

Schulz, M., Textor, C., Kinne, S., Balkanski, Y., Bauer, S., Berntsen, T., Berglen, T., Boucher, O., Dentener, F., Guibert, S., Isaksen, I. S. A., Iversen, T., Koch, D., Kirkevag, A., Liu, X., Montanaro, V., Myhre, G., Penner, J. E., Pitari, G., Reddy, S., Seland,
O., Stier, P. and Takemura, T.: Radiative forcing by aerosols as derived from the AeroCom present-day and pre-industrial simulations, Atmos. Chem. Phys., 6, 5225-5246, doi:10.5194/acp-65225-2006, 2006.

Schwarz, J. P., Spackman, J. R., Gao, R. S., Watts, L. A., Stier, P., Schulz, M., Davis, S. M., Wofsy, S. C., and Fahey, D. W.: Global-scale black carbon profiles observed in the remote atmosphere and compared to models, Geophys. Res. Lett., 37, L18812, doi:10.1029/2010gl044372, 2010.

Seland, Ø., Iversen, T., Kirkevåg, A. and Storelvmo, T.: Aerosolclimate interactions in the CAM-Oslo atmospheric GCM and investigation of associated basic shortcomings, Tellus A - Dynam. Meteorol. Oceanogr., 60, 459-491, 2008.

Shindell, D. T., Lamarque, J.-F., Schulz, M., Flanner, M., Jiao, C., Chin, M., Young, P., Lee, Y. H., Rotstayn, L., Milly, G., Faluvegi, G., Balkanski, Y., Collins, W. J., Conley, A. J., Dalsoren, S., Easter, R., Ghan, S., Horowitz, L., Liu, X., Myhre, G., Nagashima, T., Naik, V., Rumbold, S., Skeie, R., Sudo, K., Szopa, S., Takemura, T., Voulgarakis, A., and Yoon, J.-H.: Radiative forcing in the ACCMIP historical and future climate simulations, Atmos. Chem. Phys. Discuss., 12, 21105-21210, doi:10.5194/acpd-12-21105-2012, 2012.

Skeie, R. B., Berntsen, T. K., Myhre, G., Tanaka, K., Kvalevag, M. M., and Hoyle, C. R.: Anthropogenic radiative forcing time series from pre-industrial times until 2010, Atmos. Chem. Phys., 11, 11827-11857, doi:10.5194/acp-11-11827-2011, 2011.

Smith, G. L., Priestley, K. J., Loeb, N. G., Wielicki, B. A., Charlock, T. P., Minnis, P., Doelling, D. R., and Rutan, D. A.: Clouds and Earth Radiant Energy System (CERES), a review: Past, present and future, Adv. Space Res., 48, 254-263, 2011.

Spracklen, D. V., Jimenez, J. L., Carslaw, K. S., Worsnop, D. R., Evans, M. J., Mann, G. W., Zhang, Q., Canagaratna, M. R., Allan, J., Coe, H., McFiggans, G., Rap, A., and Forster, P.: Aerosol mass spectrometer constraint on the global secondary organic aerosol budget, Atmos. Chem. Phys., 11, 12109-12136, doi:10.5194/acp-11-12109-2011, 2011.

Stier, P., Feichter, J., Kinne, S., Kloster, S., Vignati, E., Wilson, J., Ganzeveld, L., Tegen, I., Werner, M., Balkanski, Y., Schulz, M., Boucher, O., Minikin, A., and Petzold, A.: The aerosol-climate model ECHAM5-HAM, Atmos. Chem. Phys., 5, 1125-1156, doi:10.5194/acp-5-1125-2005, 2005.

Stier, P., Schutgens, N. A. J., Bian, H., Boucher, O., Chin, M., Ghan, S., Huneeus, N., Kinne, S., Lin, G., Myhre, G., Penner, J. E., Randles, C., Samset, B., Schulz, M., Yu, H., and Zhou, C.: Host model uncertainties in aerosol radiative forcing estimates: results from the AeroCom prescribed intercomparison study, Atmos. Chem. Phys. Discuss., 12, 25487-25549, doi:10.5194/acpd-1225487-2012, 2012.

Szopa, S., Balkanski, Y., Cozic, A., Déandreis, C., Dufresne, J.-L., Hauglustaine, D., Lathière, J., Schulz, M., Vuolo, R., Yan, N., Marchand, M., Bekki, S., Cugnet, D., Idelkadi, A., Denvil, S., Foujols, M.-A., Caubel, A., and Fortems-Cheiney, A.: Aerosol and Ozone changes as forcing for Climate Evolution between 1850 and 2100, Clim. Dynam., in press, doi:10.1007/s00382012-1408-y, 2012.

Takemura, T., Nakajima, T., Dubovik, O., Holben, B. N., and Kinne, S.: Single-scattering albedo and radiative forcing of various aerosol species with a global three-dimensional model, J. Climate, 15, 333-352, 2002. 
Takemura, T., Nozawa, T., Emori, S., Nakajima, T. Y., and Nakajima, T.: Simulation of climate response to aerosol direct and indirect effects with aerosol transport-radiation model, J. Geophys. Res.-Atmos., 110, D02202, doi:10.1029/2004jd005029, 2005.

Takemura, T., Egashira, M., Matsuzawa, K., Ichijo, H., O’Ishi, R., and Abe-Ouchi, A.: A simulation of the global distribution and radiative forcing of soil dust aerosols at the Last Glacial Maximum, Atmos. Chem. Phys., 9, 3061-3073, doi:10.5194/acp-93061-2009, 2009.

Textor, C., Schulz, M., Guibert, S., Kinne, S., Balkanski, Y., Bauer, S., Berntsen, T., Berglen, T., Boucher, O., Chin, M., Dentener, F., Diehl, T., Easter, R., Feichter, H., Fillmore, D., Ghan, S., Ginoux, P., Gong, S., Kristjansson, J. E., Krol, M., Lauer, A., Lamarque, J. F., Liu, X., Montanaro, V., Myhre, G., Penner, J., Pitari, G., Reddy, S., Seland, O., Stier, P., Takemura, T. and Tie, $\mathrm{X}$.: Analysis and quantification of the diversities of aerosol life cycles within AeroCom, Atmos. Chem. Phys., 6, 1777-1813, doi:10.5194/acp-6-1777-2006, 2006.

Textor, C., Schulz, M., Guibert, S., Kinne, S., Balkanski, Y., Bauer, S., Berntsen, T., Berglen, T., Boucher, O., Chin, M., Dentener, F., Diehl, T., Feichter, J., Fillmore, D., Ginoux, P., Gong, S., Grini, A., Hendricks, J., Horowitz, L., Huang, P., Isaksen, I. S. A., Iversen, T., Kloster, S., Koch, D., Kirkevag, A., Kristjansson, J. E., Krol, M., Lauer, A., Lamarque, J. F., Liu, X., Montanaro, V., Myhre, G., Penner, J. E., Pitari, G., Reddy, M. S., Seland, O., Stier, P., Takemura, T., and Tie, X.: The effect of harmonized emissions on aerosol properties in global models an AeroCom experiment, Atmos. Chem. Phys., 7, 4489-4501, doi:10.5194/acp-7-4489-2007, 2007.

Thomson, A. M., Calvin, K. V., Smith, S. J., Kyle, G. P., Volke, A., Patel, P., Delgado-Arias, S., Bond-Lamberty, B., Wise, M. A., Clarke, L. E., and Edmonds, J. A.: RCP4.5: a pathway for stabilization of radiative forcing by 2100 , Clim. Change, 109, 77-94, 2011.

Tsigaridis, K., Krol, M., Dentener, F. J., Balkanski, Y., Lathiere, J., Metzger, S., Hauglustaine, D. A., and Kanakidou, M.: Change in global aerosol composition since preindustrial times, Atmos. Chem. Phys., 6, 5143-5162, doi:10.5194/acp-6-5143-2006, 2006.

Tsigaridis, K., Koch, D. M., and Menon, S.: Uncertainties and importance of sea-spray composition on aerosol direct and indirect effects, J. Geophys. Res., 118, 220-235, doi:10.1029/2012JD018165, 2013.
Vignati, E., Wilson, J., and Stier, P.: M7: An efficient sizeresolved aerosol microphysics module for large-scale aerosol transport models, J. Geophys. Res.-Atmos., 109, D22202, doi:10.1029/2003JD004485, 2004.

Wang, M. and Penner, J. E.: Aerosol indirect forcing in a global model with particle nucleation, Atmos. Chem. Phys., 9, 239-260, doi:10.5194/acp-9-239-2009, 2009.

Wielicki, B. A., Barkstrom, B. R., Harrison, E. F., Lee, R. B., Smith, G. L., and Cooper, J. E.: Clouds and the earth's radiant energy system (CERES): An earth observing system experiment, B. Am. Meteorol. Soc., 77, 853-868, 1996.

$\mathrm{Xu}, \mathrm{L}$. and Penner, J. E.: Global simulations of nitrate and ammonium aerosols and their radiative effects, Atmos. Chem. Phys., 12, 9479-9504, doi:10.5194/acp-12-9479-2012, 2012.

Yu, F.: A secondary organic aerosol formation model considering successive oxidation aging and kinetic condensation of organic compounds: global scale implications, Atmos. Chem. Phys., 11, 1083-1099, doi:10.5194/acp-11-1083-2011, 2011.

Yu, F. and Luo, G.: Simulation of particle size distribution with a global aerosol model: contribution of nucleation to aerosol and CCN number concentrations, Atmos. Chem. Phys., 9, 76917710, doi:10.5194/acp-9-7691-2009, 2009.

Zarzycki, C. M. and Bond, T. C.: How much can the vertical distribution of black carbon affect its global direct radiative forcing?, Geophys. Res. Lett., 37, L20807, doi:10.1029/2010g1044555, 2010.

Zhang, H., Wang, Z. L., Wang, Z. Z., Liu, Q. X., Gong, S. L., Zhang, X. Y., Shen, Z. P., Lu, P., Wei, X. D., Che, H. Z., and Li, L.: Simulation of direct radiative forcing of aerosols and their effects on East Asian climate using an interactive AGCM-aerosol coupled system, Clim. Dynam., 38, 1675-1693, 2012a.

Zhang, K., O’Donnell, D., Kazil, J., Stier, P., Kinne, S., Lohmann, U., Ferrachat, S., Croft, B., Quaas, J., Wan, H., Rast, S., and Feichter, J.: The global aerosol-climate model ECHAM-HAM, version 2: sensitivity to improvements in process representations, Atmos. Chem. Phys., 12, 8911-8949, doi:10.5194/acp-12-89112012, $2012 b$. 